$12-1-2021$

\title{
Economic opportunities for refugees: Lessons from five host countries
}

Md. Noorunnabi Talukder

Population Council

Abdullah Al Mahmud Shohag

Population Council

Eashita Haque

Population Council

Md. Irfan Hossain

Population Council

Joseph Falcone

See next page for additional authors

Follow this and additional works at: https://knowledgecommons.popcouncil.org/departments_sbsr-pgy

Part of the Migration Studies Commons, and the Work, Economy and Organizations Commons

How does access to this work benefit you? Let us know!

\section{Recommended Citation}

Talukder, Md. Noorunnabi, Abdullah Al Mahmud Shohag, Eashita Haque, Md. Irfan Hossain, Joseph Falcone, and Ubaidur Rob. 2021. "Economic opportunities for refugees: Lessons from five host countries." Dhaka: Population Council. 


\section{Authors}

Md. Noorunnabi Talukder, Abdullah Al Mahmud Shohag, Eashita Haque, Md. Irfan Hossain, Joseph

Falcone, and Ubaidur Rob

This report is available at Knowledge Commons: https://knowledgecommons.popcouncil.org/departments_sbsr-pgy/ 


\section{ECONOMIC OPPORTUNITIES FOR REFUGEES: LESSONS FROM FIVE HOST COUNTRIES}

MD NOORUNNABI TALUKDER ABDULLAH AL MAHMUD SHOHAG EASHITA FARZANA HAQUE MD IRFAN HOSSAIN JOSEPH P FALCONE UBAIDUR ROB 



\section{ECONOMIC OPPORTUNITIES FOR REFUGEES: LESSONS FROM FIVE HOST COUNTRIES}

MD NOORUNNABI TALUKDER ABDULLAH AL MAHMUD SHOHAG

EASHITA FARZANA HAQUE

MD IRFAN HOSSAIN

JOSEPH P FALCONE

UBAIDUR ROB

DECEMBER 2021 


\section{populatron COUNCIL \\ Ideas. Evidence. Impact.}

The Population Council confronts critical health and development issues-from stopping the spread of HIV to improving reproductive health and ensuring that young people lead full and productive lives. Through biomedical, social science, and public health research in 50 countries, we work with our partners to deliver solutions that lead to more effective policies, programs, and technologies that improve lives around the world. Established in 1952 and headquartered in New York, the Council is a nongovernmental, nonprofit organization governed by an international board of trustees.

Population Council

House 12, Road 25/30, Gulshan 1

Dhaka 1212

Bangladesh

Tel: +8802222292276

email: info.bangladesh@popcouncil.org

popcouncil.org

Suggested citation: Talukder, Md Noorunnabi, Abdullah Al Mahmud Shohag, Eashita Farzana Haque, Md Irfan Hossain, Joseph P Falcone, and Ubaidur Rob. 2021. "Economic opportunities for refugees: Lessons from five host countries." Dhaka: Population Council.

(c) 2021 The Population Council, Inc. 


\section{Table of Contents}

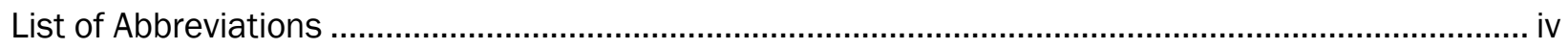

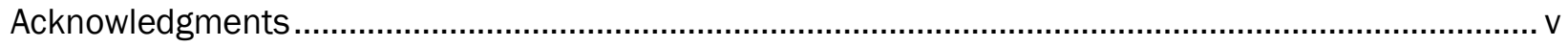

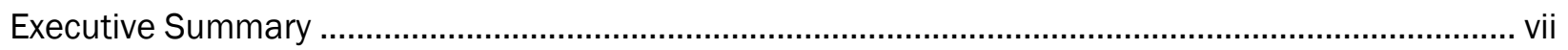

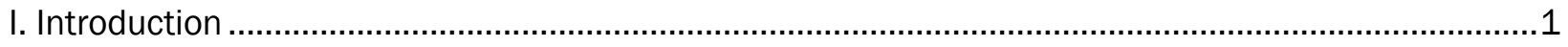

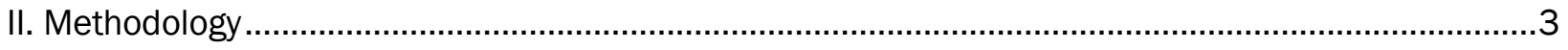

III. Lessons from Five Refugee-Hosting Countries .....................................................................

Uganda: A Model for Local Integration of Refugees ...................................................................

Ethiopia: Informal Access to Work for Refugees..................................................................... 8

Kenya: Access to Work for Urban Refugees ......................................................................... 12

Jordan: A Model for Labor Force integration of Refugees ....................................................... 16

Malaysia: No Right for Refugees to Work ................................................................................. 19

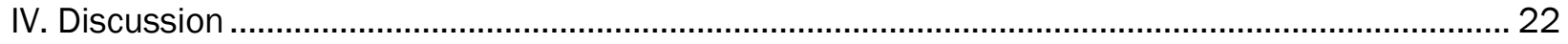

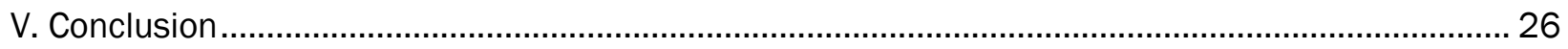

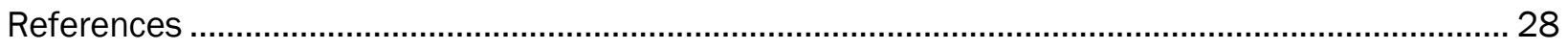




\section{List of Abbreviations}

CRRF Comprehensive Refugee Response Framework

DRC Democratic Republic of Congo

EU European Union

GoE Government of Ethiopia

GoJ Government of Jordan

GoK Government of Kenya

GoM Government of Malaysia

GoU Government of Uganda

HBB Home-Based Business

ILO International Labour Organization

MoL Ministry of Labor

NGO Nongovernmental Organization

OCP Out-of-Camp Policy

QIZ Qualifying Industrial Zone

UNHCR United Nations High Commissioner for Refugees 


\section{Acknowledgments}

This report is an outcome of the project "Assessment of Livelihood and Skills Development Opportunities for Young Rohingya Populations in Bangladesh," designed and implemented by the Population Council. We gratefully acknowledge the contribution of two individual donors, Jerry Cunningham and Diane Cunningham, for their financial support to carry out the project.

This publication is made possible by the generous support of Jerry Cunningham and Diane Cunningham. The opinions expressed in this report are solely those of the authors and should not be attributed to the donors. 


\section{Executive Summary}

\section{INTRODUCTION}

Globally, the majority of refugees are now in a protracted refugee situation, living in exile for at least five years and with no sign of a durable solution. There are three possibilities for durable solutions: repatriation, local integration, and resettlement. Repatriation remains the main durable solution for refugees, but the circumstances should be conducive for return to the country of origin. In the meantime, local integration gives refugees some certainty about what to do with their lives. Local integration can be regarded as a process with three interrelated dimensions: legal, economic, and social. For the purposes of this paper, we examined the level and extent of local integration of refugees in terms of economic inclusion.

\section{METHODOLOGY}

A review of literature was carried out to generate evidence on what works best for refugees' local economic integration in protracted refugee situations. Five countries, namely, Uganda, Ethiopia, Kenya, Jordan, and Malaysia, were included for this exercise. The criteria used to select the countries for review were a large and protracted refugee situation, initiatives on refugees' right to work, geographic diversity, and level of economic development. The review utilized both published and grey literature. Literature was identified through a systematic search and screening process. A narrative review using a simple form of data extraction was employed. The synthesis of evidence was based on three thematic focuses: refugees' right to work, economic opportunities for refugees, and integration of refugees. The report highlights the ways in which national policies and initiatives on refugees' right to work vary across five countries and the level and extent of economic integration of refugees.

\section{KEY FINDINGS}

\section{Refugee population}

Uganda is the largest refugee-hosting country in Africa, with a refugee population of almost 1.5 million. Uganda's neighbors - Ethiopia and Kenya - are also major refugee-hosting countries in Africa. Ethiopia is the third largest refugee-hosting country in Africa, with over 806,000 refugees and Kenya hosts over half a million refugees. Jordan hosts over 660,000 Syrian refugees and Malaysia is a host to over 154,000 Myanmar refugees. In all these five countries, the refugees find themselves in protracted situations and the prospect of returning to their countries of origin is slim for most and the possibilities of resettlement in third countries is currently unpredictable.

\section{Refugee right to work}

Uganda's approach is noted as a model for refugee-hosting countries around the world because of its progressive legislation granted by the 2006 Refugee Act and the Refugee Regulations 2010. In Uganda, refugees are granted a wide range of rights and entitlements, including legal right to work, freedom of movement, and access to services such as education and health. Uganda uses an open settlement policy: it allows refugees plots of land for residence and cultivation. Refugees living outside the settlement can live and buy property as permissible to any foreign nationals. There are no legal barriers to employment for refugees and they have the right to work in the same manner as nationals except for employment in government 
agencies. Uganda is a pilot country of the Comprehensive Refugee Response Framework (CRRF). ${ }^{1}$ The Ugandan government is working toward achieving self-reliance and resilience among both the refugees and refugee-hosting districts.

Ethiopia follows encampment practices, but refugees can leave the camp with a permit. Refugees are generally not allowed to work in Ethiopia, but there are no legal restrictions on informal work. Since 2010, refugees have been given the option of living outside of the camps as part of the government's out-of-camp policy. Ethiopia pursued restrictive labor policies for refugees in their country until the introduction of CRRF in 2017. The framework proposes the provision of work permits to qualifying refugees, earmarking a percentage of jobs within industrial parks, and providing access to irrigable land for refugees. Introduction of the CRRF represents a major shift in Ethiopia's refugee policy as refugees living in camps will benefit from paid employment, and those in protracted situations will have opportunities to integrate locally and live outside camps.

In Kenya, refugees in general are not allowed to work formally. Until the 1990s, refugee policy favored local integration. This integration policy was reversed in the early 1990s, when hundreds of thousands of refugees arrived in Kenya. Then, the Kenyan government made a major shift in its refugee policy away from integration and toward encampment. The 2006 Refugee Act conferred progressive rights to refugees. As a result, the Kenyan government assumed more responsibility in registration and legal protection of refugees. The Act also provided refugees the same rights to employment as other non-nationals and allowed them to have work permits. Refugees have the option of obtaining work permits, usually for two years, as permissible for nonnationals. Camp residents in possession of a movement pass can travel to other parts of Kenya.

Since 2016, the Jordanian government has allowed both urban refugees and those refugees in the camps a legal right to work. The government allows refugees to have work permits in certain occupations open to immigrants/non-Jordanians. Camp refugees are allowed to work outside the camp which is conditional upon securing legal permission to leave. Agricultural cooperatives allow free-of-charge work permits for refugees. In November 2018, the Jordanian government issued a decision allowing refugees to establish their own homebased businesses in food processing, tailoring, and handicrafts.

Malaysia is not a signatory to the UN Convention on Refugees. The country has no legal or administrative framework for dealing with refugees. Malaysia, on humanitarian grounds, generally allows asylum seekers and refugees to stay in the country. Refugees are allowed to live in local communities once registered. The Government of Malaysia's current position is that refugees are not allowed to work lawfully in Malaysia, and few receive assistance. The government has implemented several work permit schemes for small, select groups of refugees, but so far its policies are ad hoc.

\section{Economic integration of refugees}

Uganda has a long history as a host country for refugees, and the integration of refugees into Ugandan society has been a common occurrence. The legal structures of Uganda have shaped, and continue to shape, the possibilities for local integration of refugees in this country. The Ugandan government's approach to hosting refugees is broadly characterized by opening its doors to all refugees; recognizing a wide array of rights of refugees; confirming their implicit coverage by national policies, strategies, and plans; and integrating refugees into local populations, e.g., via use of the same health, education, and agricultural extension services. In

\footnotetext{
1 In September 2016, the United Nations General Assembly unanimously adopted the New York Declaration for Refugees and Migrants. The New York Declaration sets out the key elements of a CRRF to be applied to large-scale movements of refugees and protracted refugee situations. The CRRF is a multi-stakeholder coordination model on refugee matters focusing on humanitarian and development needs of both refugees and host communities. UNHCR has been working with countries and all other relevant stakeholders to develop and initiate the practical application of the CRRF in several countries.
} 
Uganda, refugees are legally allowed to engage in both agricultural and a wide variety of non-agricultural economic activities. The Ugandan government's experience on local integration in harnessing development aid for the mutual benefit of refugees and their hosts provides important lessons for policymakers and aid organizations working in other host countries.

Ethiopia is a host country where there is no legal right to work, but informal work is permitted in practice. In camps, refugees mostly survive on humanitarian assistance. Some are engaged in economic activities within the camp or in the neighboring host markets. Refugees have access to incentive work ${ }^{2}$ from UN agencies and local NGOs. On the other hand, refugees settled in urban areas become progressively integrated there in economic and social terms. Currently, the government of Ethiopia is in the process of adopting the CRRF approach, similar to that of Uganda, on local integration of refugees. The strategy is to shift from a camp-based model of refugee assistance to an approach which emphasizes refugee self-reliance and in-country refugee mobility. Thus, local integration of refugees has become a possibility, but more efforts are required to assess how it can be made an operational and sustainable reality.

In Kenya, a number of elements for informal integration exist for urban refugees. Urban refugees find employment and self-employment opportunities mostly in the informal sector, which is highly competitive. Outside the camp, some refugees are considered to have achieved a form of de facto integration as they have become self-reliant through employment in the informal sector in Nairobi, are able to access some health and educational services, and are socially networked into the host community. On the other hand, the local integration of camp refugees is hard to achieve due to Kenya's policy of encampment. Because of the remote location of the camps and refugees' physical curtailment, their socioeconomic opportunities are constrained by a lack of mobility and right to work.

Jordan's initiatives on labor force integration of refugees are seen as a durable solution. The Jordanian government has taken an unprecedented step to support the integration of Syrian refugees into its labor force. Jordan allows Syrian refugees to obtain legal work permits in its labor market and to pursue employment opportunities in "sectors open to immigrants" such as agriculture, construction, services, wholesale trade, and manufacturing in special economic zones. Jordanian exporters can enjoy trade benefits from European Union countries in return for employing a minimum percentage of Syrian refugees. Syrian refugees in Jordan form an important demographic in the labor market, comprising one-fifth of the total non-Jordanian workforce. Refugee labor integration does not harm Jordan's labor force, because Syrian refugees are working in the sectors dominated by other migrant laborers.

Malaysian policy does not support local integration of refugees. However, many refugees work in the informal sector, rent accommodations, access health care at government facilities, and pray at Malaysian mosques. Yet many refugees spend years, decades, and even generations living in limbo, lacking the prospect of a formal durable solution. The Malaysian government has pledged to allow refugees to work in the country; implementation of this policy has, however, been slow. In the absence of strong political will within the government, refugees in Malaysia can only be informally integrated into the economy and community, with no future for themselves and the generation to come.

\section{CONCLUSION}

Refugee integration is determined by the conditions and environment in which their settlement occurs. Refugees can be considered integrated with host economies when they have access to work permits and business licenses, are able to secure livelihoods, and become less reliant on humanitarian assistance.

\footnotetext{
2 Humanitarian agencies can hire refugees as "incentive workers" for a fraction of the salary that host-country nationals would receive in the same post, and the rates are well below the minimum wage.
} 
Opportunities for refugees to work are subject to the national policies and initiatives of host countries. A comparison of the situation on legal right to work reveals a highly favorable condition for refugee rights in Uganda among the five reviewed countries. Uganda has a national policy and well-defined framework permitting refugees to work. In Jordan and Kenya, a certain proportion of refugees are allowed to work in strictly defined sectors and occupations. In Ethiopia refugees are not allowed to work, but there are no legal restrictions on informal work. The Ethiopian government is now focusing on measures to extend refugee rights and relax its camp-based approach. Malaysia is found to be the most restrictive in terms of granting work rights to refugees.

Of the five refugee-hosting countries, Malaysia is the most restrictive and least progressive with regard to integrating refugees locally. Ethiopia is the next most restrictive host country in terms of refugee integration. In host countries like Ethiopia with no existing national policy that respects refugees' right to work, but no legal restrictions on informal work, the potential for inclusion of refugees in the formal economy is high. In host countries like Malaysia, where national policy prohibits refugees from working, there is no alternative but to facilitate policy development to grant refugees the right to work. Advocacy efforts should build on the evidence base demonstrating the potential and the positive impact that economic inclusion can have on refugees and host communities.

A multicounty analysis of local integration of refugees has important implications for any host countries to ensure the provision of employment and work for refugees. There are, however, differences in the economy and labor market functions between countries, which pose challenges to policymakers and aid organizations. None of the five countries belongs to the high-income economies. Uganda and Ethiopia are low-income countries, Kenya lower-middle income, and Jordan and Malaysia upper-middle income. In the three African countries included in this review, the labor market is mostly informal, while labor markets in Malaysia and Jordan are largely formalized. The Ugandan model and the Jordanian approach are worthy of being replicated in socioeconomically comparable host countries. Uganda provides a unique context for the investigation of local integration as a durable solution. Uganda's refugee legislature and policy are known worldwide, and Ethiopia to some extent has begun to apply similar measures, as both these countries contain comparable histories and socioeconomic contexts. Jordan's initiative to integrate refugees into the labor market may be a suitable measure for the upper-middle income economies having a more formalized labor market, like Malaysia. Yet, the predetermined model or framework should not be readily adopted in situations of protracted displacement without examining the legal, economic, and socio-cultural realities specific to the refugee context. 


\section{Introduction}

Globally, the majority of refugees are now in a protracted refugee situation, with no sign of a durable solution. Situations of displacement are varied and subject to continuous change and there is rarely a predictable path from displacement to return. In 2004, the United Nations High Commissioner for Refugees (UNHCR) defined a major "protracted" refugee situation as a situation of 25,000 or more refugees that had been in existence for five or more years with no immediate prospect of a durable solution. They are not always static populations; there are often periods of increase and decrease in the numbers of people displaced and changes within the population. Currently, nearly two-thirds of the world's refugees are in situations of seemingly unending exile. According to UNHCR, the 25 countries most affected by a prolonged refugee presence are all in the developing world. There are some 30 major protracted refugee situations around the world. The average length of stay in these states of virtual limbo is now approaching 20 years, up from an average of nine years in the early 1990s. Thus, not only is a greater percentage of the world's refugees in protracted exile than before but these situations are lasting longer (Milner and Loescher 2011).

For refugees, there are three possibilities for durable solutions: repatriation, local integration, and resettlement (Crisp 2003). Repatriation remains the main durable solution for refugees, but the circumstances must be

\section{BOX 1 Durable Solution for Refugees}

Once refugee status has been determined and immediate protection needs are addressed, refugees may need support to find a long-term, durable solution. The concept of durable solution has traditionally been associated with permanent settlement, whether in the host country, a third country, or the country of origin. UNHCR promotes three durable solutions for refugees as part of its core mandate:

- Voluntary repatriation

- Local integration

- Resettlement

There is no hierarchy of durable solutions; rather, an integrated approach that combines all three solutions and is implemented in close cooperation with countries of origin, host countries, humanitarian and development actors, as well as the refugees themselves usually offers the best chances for success.

Source: 50a4c17f9.pdf (unhcr.org)

Repatriation: Repatriation may be one solution for refugees when they find it conducive to return to their home country in safety and dignity. Voluntary return to the country of origin is not immediately feasible.

Resettlement: For those who cannot return, either because of continued conflict, wars, or persecution, resettlement in a third country is one alternative.

Local integration: Another alternative for those who are unable to return home is integration within the host community. This is often a complex process which places considerable demands on both the individual and the receiving society. However, it also has benefits, allowing refugees to contribute socially and economically.

Source: UNHCR - Solutions conducive for return. UNHCR works with hostcountry governments to find durable solutions for each refugee and asylum seeker. Humanitarian assistance is often provided to refugee populations in the early phases of displacement, but protracted displacement requires a shift to multiyear, more development-oriented programming to promote self-reliance among refugee populations and to reduce their dependence and that of host communities, where such support is also provided, on costly external assistance (Mathys 2016).

In striving for sustainable interventions in situations of protracted displacement, UNHCR and donor countries are left with little option but to consider initiatives aimed at local integration. Rhetorically, integration has always been a guiding principle of refugee programs in countries of the Global South. According to the 1951 UN Refugee Convention, restoring refugees to dignity and ensuring the provision of human rights includes an approach that would lead to their integration in the host society. More recent thinking, however, emphasizes both the importance of maintaining individual identity and the possibility of promoting self-reliance pending voluntary return, whereby local integration could be temporary (Dryden-Peterson and Hovil 2004).

The notion of "local integration" is frequently used in the refugee context, and yet it lacks any formal definition in international refugee law. According 
to Crisp (2004), local integration can be regarded as a process which leads to a durable solution for refugees. It is a process with three interrelated dimensions. First, it is a legal process, whereby refugees are granted a progressively wider range of rights and entitlements by the host state. Under the terms of the 1951 Refugee Convention, these include, for example, the right to seek employment, to engage in other income-generating activities, to own and dispose of property, to enjoy freedom of movement, and to have access to public services such as education. Second, local integration can be regarded as an economic process. In acquiring the rights and entitlements referred to above, refugees also improve their potential to establish sustainable livelihoods, to attain a growing degree of self-reliance, and to become progressively less reliant on state aid or humanitarian assistance. In accordance with these indicators, refugees who are prevented or deterred from participating in the local economy, and whose standard of living is consistently lower than the poorest members of the host community, cannot be considered to be locally integrated. Third, local integration is a social process, enabling refugees to live among or alongside the host population, without fear of systematic discrimination, intimidation, or exploitation by the authorities or people of the asylum country. It is consequently a process that involves both refugees and the host population (Crisp 2004).

For the purposes of this report, we highlighted the refugee legal rights situation and then examined the level and extent of local integration of refugees in terms of economic inclusion. In line with the study design, this report does not discuss social integration of refugees. In particular, the report reflects on the refugees' right to work and their access to the labor market and potential to establish sustainable livelihoods in five selected countries with protracted refugee situations. 


\section{Methodology}

The purpose of the review is to generate evidence on what works best for refugees' economic integration in protracted refugee situations in five selected countries. The steps to conduct this secondary research included:

- Country selection. Five countries, namely, Uganda, Ethiopia, Kenya, Jordan, and Malaysia, were selected to understand refugee integration in different parts of the world. A protracted refugee situation with large agglomerations of refugees (more than 100,000 refugees) was the key criterion for selecting the countries for review. In selecting the countries, geographic diversity was also accounted for. The presence of any pledges or initiatives on refugees' right to work was another selection criterion. The high-income countries that host refugees were excluded from the review.

Uganda was included because the country hosts the largest refugee populations in Africa and because it is a country with many refugees experiencing protracted displacement. Similarly, Ethiopia and Kenya are also major refugee-hosting countries in Africa. Ethiopia is the third largest refugee-hosting country in Africa, with over 806,000 refugees, and Kenya hosts over half a million refugees. Jordan hosts over 660,000 Syrian refugees and Malaysia is a host to over 154,000 Myanmar refugees. None of the five countries belongs to the high-income economies. Uganda and Ethiopia are low-income countries, Kenya lower-middle income, and Jordan and Malaysia upper-middle income. In these five countries, the refugees find themselves in protracted situations, the prospect of returning to their countries of origin is slim for most of the refugees, and the possibilities of resettlement in third countries is currently unpredictable. Bangladesh, a lower-middle income country in South Asia, hosting about one million Myanmar refugees, was excluded because we conducted a separate study for Bangladesh based on primary data under this project.

- Literature search. The review utilized both published and grey literature. Journal articles, working papers, evaluation reports, project reports/briefs, conference papers, and newspaper articles were collected for review. Literature describing country experiences older than 10 years was excluded. The review was based on the literature retrieved from an online search. Search terms included: refugee integration, local integration of refugees, refugees' right to work, economic opportunities for refugees, and livelihood opportunities for refugees. The search also included the names of UN agencies and international nongovernmental organizations (NGOs) working with refugees. In addition, literature was collected through an online search of the websites of the host government ministries and departments of refugee affairs. The search followed the websites of research institutes working with refugee and international migration issues. From the selected literature, the bibliographies were checked to identify papers missed in the initial search/compilation. Literature containing information on two aspects of refugee integration-legal and economic-were selected for review.

- Evidence synthesis. The review started with summarizing each piece of the selected literature through a uniform review format. A narrative review using a simple form of data extraction was employed to achieve an understanding about the policies and initiatives, as well as to assess the impact of these initiatives where available, i.e., to generate knowledge on what approaches show the most promise for addressing refugee right to work as well as the potential for local integration of refugees. Two reviewers were employed to reduce bias. The review findings were compiled by country, and then summarized and synthesized. The synthesis of evidence was based on three thematic focuses: refugees' rights to work, economic opportunities of refugees, and integration of refugees. A narrative account of findings is presented. 


\section{Lessons from Five Refugee-Hosting Countries}

\section{UGANDA: A MODEL FOR LOCAL INTEGRATION OF REFUGEES}

By May 2021, almost 1.5 million refugees lived in Uganda with around 62 percent of all refugees in Uganda from South Sudan and another 29 percent from the Democratic Republic of the Congo (DRC). The remaining 9 percent of refugees were from three countries: Burundi, Somalia, and Rwanda (UNHCR 2021a).

\section{A. Legal context}

The Government of Uganda (GoU) has a progressive policy approach to refugees, which recognizes a range of refugee rights, including the right to land, freedom to work, unrestricted mobility, and the right to essential social services. The two most important national legal instruments that explicitly address refugees are the GoU Refugee Act 2006 and the GoU Refugee Regulations 2010. The Refugee Act 2006 defines the term "refugee" and outlines the rights and responsibilities of refugees in Uganda. The law states that refugees have the right to work, freedom of movement, and the right to live in settlements, all of which are designed to support selfreliance. The GoU Refugee Regulations 2010 further clarify the rights and obligations of refugees under Ugandan law, in accordance with international standards and conventions (Mathys 2016).

\section{BOX 2 Comprehensive Refugee Response Framework}

On 19 September 2016, the United Nations General Assembly unanimously adopted the New York Declaration for Refugees and Migrants. The New York Declaration sets out the key elements of a Comprehensive Refugee Response Framework (CRRF) to be applied to large-scale movements of refugees and protracted refugee situations. The CRRF focuses on the importance of supporting those countries and communities that host large number of refugees, promoting the inclusion of refugees in host communities, ensuring the involvement of development actors from an early stage, and developing a "whole-of-society" approach to refugee responses. Its four key objectives are to:

- Ease the pressures on host countries and communities

- Enhance refugee self-reliance

- Expand third-country solutions

- Support conditions in countries of origin for return in safety and dignity

The CRRF is a multi-stakeholder coordination model on refugee matters focusing on humanitarian and development needs of both refugees and host communities. UNHCR has been working with countries and all other relevant stakeholders to develop and initiate the practical application of the CRRF in a number of countries. Uganda is the first country in Africa to apply CRRF.

Source: https://www.unhcr.org/new-york-declaration-forrefugees-and-migrants.html
Moreover, Uganda is a pilot country of the Comprehensive Refugee Response Framework (CRRF). Since 2016, Uganda has implemented the Refugee and Host Population Empowerment strategy which aims to harmonize the refugee response in Uganda by integrating refugee programming into the national development plan. This strategy is a key component of the CRRF in Uganda, a multi-stakeholder approach with the objective of easing pressure on host countries and enhancing self-reliance of refugees (Bohnet and Schmitz-Pranghe 2019).

\section{B. Economic opportunities for refugees}

\section{Access to land}

Provision of land to refugees. Uganda's settlement approach foresees that refugees be given a plot of land under the premise that this enables self-reliance in the medium- and longrun. The norm has been to provide $30 \times 30$ square meters of residential land and 50x50 square meters for agriculture purposes to a household. Refugee settlements are understood as long-term structures that offer the possibility for a degree of self-sufficiency as opposed to camps (Bohnet and Schmitz-Pranghe 2019). 
Settlement criteria. Uganda's settlement approach is based on the principle of equity in welfare and service provision between refugees and host communities. The local population provides land for a refugee settlement in exchange for schools and health centers in the host community. So far, there is an agreement that 30 percent of international refugee assistance should directly target receiving communities. However, this agreement is contested, and districts are increasingly pushing for a 50/50 ratio (Bohnet and Schmitz-Pranghe 2019).

\section{Access to livelihood, employment, and business opportunities}

In Uganda, refugees are placed within specific settlements by country of origin. In settlements, refugees receive food or cash assistance for the first five years after arrival. Many refugees adopt livelihood coping strategies. Refugees are allowed to engage in both agricultural and non-agricultural economic activities. Economic opportunities for refugees in terms of employment (formal and informal) and access to productive capital vary in rural and urban areas. More than 78 percent of refugees in rural settlements are engaged in agricultural activities compared with 5 percent in urban areas. A variety of nonfarm activities supplement agriculture, including trade, which is facilitated by the freedom of movement and right to work per the Ugandan Refugee Act. Business enterprises such as bars, hairdressing, milling, transportation, money transfers, and retail are run by refugees. In terms of employability and the economic integration of refugees, almost 43 percent are actively engaged in the labor market of their host communities: 12 percent in the formal sector and 31 percent self-employed (World Bank 2016).

There are variations in economic activities between refugees of different origins. In Ugandan settlements for Sudanese refugees, not many opportunities besides agriculture exist. The primary non-agricultural incomegenerating activities for refugees and Ugandans in areas receiving the most refugees are small businesses or petty trade. The major sources of income are retail trading and selling fruit and vegetables. Sudanese refugees also try to access bigger markets, where they get fruit cheaper and then sell the same fruit at a higher price within their village (Bohnet and Schmitz-Pranghe 2019).

A comparative study on the economic outcomes of Congolese, Rwandan, and Somali refugees found that Congolese and Rwandan refugees are most likely to engage in agricultural activity, farming their own plots or working as farm laborers on the plots of other refugees. Where Congolese and Rwandans do engage in entrepreneurship, it is mainly through small shops, hawking, or bars and restaurants. In contrast, Somalis almost entirely shun agricultural work and instead engage in a huge range of entrepreneurial activities. Somali entrepreneurs are more likely to scale a business to the point at which they can employ others. In urban areas, the pattern differs. In urban Kampala, 95 percent of Congolese are self-employed, 78 percent of Rwandans, and just 26 percent of Somalis (Betts, Omata, and Bloom 2017).

Economic activities of the refugees from a country vary by their location. Congolese refugees in Rwamwanja Settlement practice predominantly agricultural livelihoods. The most important income sources for refugees in Rwamwanja were crop production and sale, followed by agricultural wage labor. Refugees in Rwamwanja supplement agricultural labor with a range of income-generating activities (Government of Uganda, UNHCR, and World Bank 2016). Congolese refugees living elsewhere in Uganda portray diverse livelihood patterns including on-farm and off-farm activities. Among refugees in Kyangwali and Nakivale Settlements, Congolese refugees most frequently reported that their top source of livelihood was farming their own plots, followed by farm labor for others, construction work, running a small shop, or employment with an organization. Congolese refugees who have self-settled in urban areas, primarily in Kampala, were the most likely to report engagement in various types of businesses (e.g., selling clothes or textiles, tailoring, brokerage, or providing hair and beauty services) as their top source of livelihood, rather than agriculture (Betts et al. 2014).

Refugees have higher income and lower dependency levels in the city compared with those in settlements. In terms of dependency on aid agencies, most refugees in Kampala do not receive any form of assistance from the aid agencies, and therefore only 9.4 percent of total respondents consider their households "very 
dependent" on support from UNHCR and other aid agencies. In contrast, in the settlement refugees are highly dependent on assistance. In Nakivale and Kyangwali, 59 percent of refugees are "very dependent" on assistance from aid organizations, and it is much higher in Rwamwanja with 78 percent (Betts, Omata, and Bloom 2017).

\section{Challenges for refugees to access employment and business}

Bohnet and Schmitz-Pranghe (2019) identified inadequate infrastructure as a factor limiting refugee access to employment and business opportunities. Despite the right of refugees to work in Uganda, employment opportunities are minimal as a result of the remote location of many settlements within economically weak regions of the country, considerable constraints to the freedom of movement, and insufficient education and training opportunities. Settlements are less economically integrated. Refugees are mainly engaged in livelihood activities associated with low incomes and no job security. Many refugees cannot benefit from their right to employment or free movement because the refugee settlements offer hardly any sustainable job opportunities, and infrastructure that would connect refugees with markets is poor. Even if they manage to establish a small business, buyers and markets are insufficient to attain self-reliance. Thus, most refugees remain reliant on food rations which lately have also been reduced (Bohnet and Schmitz-Pranghe 2019).

Additionally, Betts, Omata, and Bloom (2017) found that the greatest barriers to businesses is lack of access to finance and capital, given restrictions on refugees' access to formal banking facilities. This was most significantly identified by self-employed Congolese in Kampala. Other reported barriers included the price of government business permits, xenophobia and discrimination, and language barriers (Betts, Omata, and Bloom. 2017).

\section{Integration of refugees}

Uganda has a welcoming context for refugees in the region that is exemplary compared to all other countries that host refugees. The Ugandan government's approach to hosting refugees is broadly characterized by: opening its doors to all refugees; recognition of a wide array of rights of refugees; confirming their implicit coverage by the Ugandan Constitution as well as national policies, strategies, and plans; integration of

\section{BOX 3 Refugee integration in Uganda}

Uganda's progressive approach is held up as a model for

other countries. The approach is one focused on self-

reliance as part of long-term approaches.

- Refugees are not held in camps and they can work and access services such as education and health on par with nationals.

- Inside the settlement, they are given plots of land for residence and cultivation. However, these lands are given on tenure. Refugees living outside the settlement can live and buy property as permissible to any foreign nationals.

- Refugees are entitled to identity cards and birth and death registration with fees waived.

- Education is available for refugee children and primary education is free, similar to that of Ugandan children.

- $\quad$ There are no legal barriers to employment for refugees and they have the right to work in the same manner as nationals except that refugees are not allowed to seek employment in government agencies.

- Refugees can access credit such as mortgages, as any other foreign national can. refugees into local populations (e.g., via use of the same health, education, and agricultural extension services); promoting their self-reliance; and seeking equity in welfare and service provision between refugees and hosting-district populations (Mathys 2016).

The GoU demonstrates a commitment to linking humanitarian aid with development initiatives in order to support refugees in reaching their durable solutions. Significant progress has been made in terms of integrating refugees into Uganda's National Development Plan II. The major policy initiative adopted by the Ugandan government toward integration of refugees is the CRRF, which aims to provide support for the development of sector-specific response plans in refugee-hosting districts (Bern 2016).

Uganda strongly envisions the integration of services to host and refugee populations. Integrated 
services to refugee-hosting areas are provided ensuring that refugees and host communities benefit from shared, rather than parallel, services. Shared services among refugees and their hosts provide a platform for the integration of refugees. Health and education services are considered to be the most integrated services. Refugee children are allowed to access government-aided schools, use the Ugandan curriculum, and are taught in English as the common language of instruction. Both refugees and Ugandan nationals can access free primary health care at facilities (Bern 2016).

There are gaps between intentions in policy and reality for integration of refugees in the Ugandan context. Even though refugees in Uganda, in theory, have access to land, employment, and education, and have the right to free movement, the situation on the ground provides a different picture. Most refugees have so far not achieved the goal of local integration, i.e., the ability to sustain a living and being socially integrated into the local Ugandan community. However, refugees with some income or ability to fend for themselves are selfsettled in urban centers (Bohnet and Schmitz-Pranghe 2019).

Uganda is a low-income country, which hosts about 1.5 million refugees. The following are recommendations based on the Ugandan case study for policymakers and aid organizations to apply in other low-income, refugee-receiving contexts:

- Merely establishing the right to employment, free movement, and a plot of land for refugees does not suffice to guarantee the self-reliance or local integration of refugees. Instead, governments and aid organizations must make sure that refugees can also benefit from their rights by providing the necessary infrastructure so that they can move freely and access markets.

- Refugees and local communities should be addressed in the same manner by the Ugandan government and aid agencies to prevent competition and conflict, since locals are often no better off than refugees. 


\section{ETHIOPIA: INFORMAL ACCESS TO WORK FOR REFUGEES}

Ethiopia is currently the third largest refugee-hosting country in Africa, with 806,541 refugees as of 31 May 2021. The refugees are South Sudanese (46 percent), Somalis (26 percent), Eritreans ( 21 percent), Sudanese (6 percent), and other nationalities (1 percent) (UNHCR 2021b). Most of these refugees reside in camps located in remote areas near their respective country's borders, with limited schools, health facilities, food, clean water, sanitation, and household energy (Yusuf and Khalif 2018).

\section{A. Legal context}

The Government of Ethiopia (GoE) generally maintains an open-door asylum policy and has hosted refugees from neighboring conflict-affected countries for decades. Despite having an open-door policy toward refugees, there is no provision in Ethiopian law for local integration and there are considerable restrictions on refugee freedom of movement, with the government maintaining an encampment policy for the majority of refugees (Brown et al. 2018a).

The GoE enforced an encampment policy that required all refugees to live in designated camps, barred refugees from the labor market, and imposed restrictions on other key rights related to economic inclusion, including property ownership and the ability to access financial services. In 2010, to reduce reliance on the camp system, the government began to loosen some of the restrictions on refugees with the passage of an Out-of-Camp Policy (OCP) that allowed refugees to apply for permits to live outside camps (Graham and Miller 2021).

To apply for an OCP permit, refugees must have lived in the camps for three months, have no criminal record, and must demonstrate that they can support themselves, usually through relatives or remittances (Brown et al. 2018a). They must be sponsored by a relative who is an Ethiopian citizen, who signs an agreement with the relevant Ethiopian authority that they can cover the refugee's living expenses. For many refugees, the sponsor requirement is a major barrier. OCP beneficiaries are given the right to reside outside the camps, but they are still not granted the right to work and must therefore work informally, if at all. In practice, informal livelihoods are tolerated-and recently even supported through government-sanctioned livelihood programs. As of 2018, there were almost 20,000 OCP beneficiaries, about 2 percent of all refugees in the country at that time (Graham and Miller 2021).

Fortunately, the country is making progress-albeit somewhat slowly. In 2016, Ethiopia took a major step toward a more inclusive refugee legal framework. In September of that year, at the Leaders' Summit on Refugees in New York, the GoE made "Nine Pledges" related to increasing the economic and social inclusion of refugees in the country (see Box 4). These pledges represented a major policy shift and positioned Ethiopia as an emerging leader in progressive refugee policy (Graham and Miller 2021). The strategy aims to gradually phase out the camp-based assistance model the country has been implementing for decades (Abebe 2018).

\section{B. Economic opportunities for camp refugees}

Currently, Ethiopian law dictates that most refugees, with relatively few exceptions, must live in the designated camps throughout the country, and very few refugees have been granted the right to work. Thus, most refugees lack freedom of movement and can only work informally in the limited markets in and around camps or risk living illegally outside camps. Although most refugees worked in agriculture or pastoralism prior to being displaced, few have access to land. There are limited pathways to obtaining work permits, so most refugees do not have access to formal labor markets and face potential harassment, exploitation, and criminal charges working in the informal market. Moreover, unclear regulations inhibit refugees' access to financial services, and the few refugees who live outside camps have trouble accessing government services (Graham and Miller 2021). 
Refugees are not allowed to work in Ethiopia. Yet, they engage in the economy and interact with host communities through incentive work for local NGOs and UN agencies, the sale of rations on local markets, engagement in small business activities supported by livelihoods programming, informal trade and economic exchange with host communities, or work through informal agreements with local employers (ReDSS 2018).

Conditions for economic activities are challenging in the camp. Nevertheless, refugees are actively engaged in economic activities. The Jigjiga region in eastern Ethiopia bordering Somalia hosts Somali refugees across three refugee camps. The area is resource-poor, remote, and refugees are constrained in their freedom of movement and right to work. Nonetheless, many refugees continue to pursue economic activities, particularly trade in small ruminants and informal business activities in other trade and services. Generally, the markets are well-integrated with local host communities, who engage in similar business activities and who constitute key consumers and suppliers to the camps' markets (Yusuf and Khalif 2018).

There was strong resilience among refugee business owners considering the context in which they operated. Other factors enhancing livelihood opportunities were the existence of social capital and networks, collective efforts within the camps such as group savings and lending, and the existence of some skill sets acquired formally or informally. It was also noted that the cash transfer programming implemented in the camps was fueling spending and some investments, and improved household well-being (Yusuf and Khalif 2018).

In the camp, a number of factors hindered refugee businesses, including restrictions on movement and lack of access to capital, lack of refugee markets and business spaces within the camps, and inadequacy of business skills. Furthermore, with the encampment policy, locally produced goods could not be marketed. Even though the number of businesses in the refugee camps continues to rise, the market potential will limit growth unless new growth sectors emerge, or the potential of existing sectors is unlocked (Yusuf and Khalif 2018).

Some organizations were supporting livelihoods initiatives (mainly in agriculture and livestock, vocational skills, microfinance, and income-generating activities) for host and refugee communities, though the projects implemented were small, reaching a limited number of refugees. Refugees' vocational skills were not good enough to get employment. The skills trainings were also not supported by access to labor market information, placement, or job-search support (Yusuf and Khalif 2018).

\section{Economic opportunities for refugees in urban setting}

Although still relatively small, Addis Ababa's refugee population is the largest urban refugee population in Ethiopia. There are an estimated 31,000 refugees in Addis Ababa. Refugees are permitted to live in Addis Ababa if they have specialist medical needs or face serious protection concerns. In addition, refugees from non-neighboring countries without designated camps (e.g., Yemen, Syria, and Afghanistan) and Eritrean refugees are granted OCP status. There is no formal policy for granting urban refugees' access to services such as education, water, or health care, and refugees are not incorporated in urban development plans at federal or local levels. Furthermore, there are limited protection mechanisms in the city for urban refugees (Brown et al. 2018a).

Refugee economies are diverse and highly integrated into the city's economy and make significant contributions in terms of job creation and in developing local and international markets.

Though informal, there are several positive developments in the labor market of Addis Ababa. Informal employment was widespread with refugees employed in Ethiopian-owned and refugee-owned informal enterprises or joint refugee-Ethiopian owned shops. Refugees were also employed as casual day laborers in construction. A significant number were skilled workers (e.g., electricians, welders, or mechanics). Running informal enterprises is another major source of income for refugees in Addis Ababa. Many refugees were selfemployed or ran micro-enterprises. They ran informal enterprises involved in service provision (such as hairdressing, laundry, translation, rental brokers, plumbers, and mechanics), retail, leisure and hospitality 
businesses, and construction. Some enterprises were run under a license belonging to an Ethiopian (Brown et al. 2017).

Business clusters are formed and new markets for both local and refugee communities created. Reciprocal employment was common, as both local and refugee businesses sought to reach customers in the other community (local or refugee). Some Ethiopian-owned businesses employed refugees, but the majority of businesses said they would hire refugees if the practice were legal. On the other hand, more than half of refugee-owned businesses employed Ethiopians as waiters, hairdressers, retail workers, guards, and mechanics. In addition, skilled refugees worked in local schools, hospitals, nightclubs, and formal organizations. Refugees were employed informally by formal organizations, for example as nurses in private clinics and as translators (Brown et al. 2017).

Though government officials suggest that informal work is tolerated, in practice refugees face considerable livelihood challenges. Limited access to employment resulting from the lack of a legal right to work is the most significant barrier to securing refugee livelihoods. Lack of access to business licenses means most refugee-run businesses operate under a license belonging to an Ethiopian business, limiting reinvestment and growth potential. With no labor protections, refugees face workplace discrimination that includes low wages, wages being withheld, or payments being made in the form of "incentive money" rather than regular salaries, or employment being ended arbitrarily (Brown et al. 2017).

\section{Integration of refugees}

Ethiopia's refugee policy requires refugees to live in camps, with the exception of a small number of people who are allowed to stay in urban centers because of serious protection concerns or special health needs. Since 2010, many more have been given the option of living outside the refugee camps as part of the government's OCP initiative. All OCP beneficiaries are required to sustain themselves financially (Abebe 2018).

Generally, Ethiopia has pursued restrictive labor policies for refugees. Refugees mostly survive on humanitarian assistance, which in some situations has created aid dependency. Some are engaged in economic activities within the camp or in the neighboring host markets. The isolation of the camps coupled with restrictions on access to labor markets and employment resulted in a challenging environment for sustainable livelihoods for refugees (Yusuf and Khalif 2018). On the other hand, refugees settled in urban areas become progressively integrated there in economic and social terms. Overall, the refugees' economies and the success of their livelihood efforts were constrained by a number of factors, most of which were external to them, including the GoE policies, the rules and regulations in place, and the absence of and lack of access to supporting functions.

The GoE has begun to implement policy changes in order to create more economic and social rights for refugees. For example, in 2017 Ethiopia agreed to be a pilot country for the CRRF, an approach to supporting refugees and host communities led by the UNHCR that aims to create conditions for greater refugee selfreliance-by reducing encampment and increasing access to local economies and labor markets-while also providing increased support to hosting countries, expanding opportunities for resettlement, and fostering conditions for voluntary return (Graham and Miller 2021). The CRRF serves as a means to implement the "Nine Pledges" and envisions bringing durable solutions for refugees and supporting host communities. Key pledges include providing work permits to qualifying refugees, facilitating local integration to those in protracted situations, earmarking a percentage of jobs within industrial parks, and providing access to irrigable land for refugees (Abebe 2018). 


\section{BOX 4 Ethiopia's Nine Pledges}

1. Expand the number of OCP beneficiaries to 10 percent of the total refugee population.

2. Increase school enrollment for refugees.

3. Provide work permits to refugees with permanent residence IDs.

4. Provide work permits to refugees in the areas

permitted for foreign workers.

5. Make irrigable land available to 100,000 people,

including refugees and host communities.

6. Build industrial parks and set aside a percentage of

jobs in these parks for refugees.

7. Make more documentation available to refugees,

including birth certificates and, possibly, driver's

licenses. Allow refugees to open bank accounts.

8. Expand and enhance the provision of basic social

services for refugees.

9. Allow local integration for refugees who have lived in

Ethiopia for 20 years or more.

Source: Ethiopia CRRF Roadmap, March 2018

https://data2.unhcr.org/en/documents/details/62655
With the Nine Pledges, there is a window of opportunity to allow for economic integration and use that as a medium for social cohesion and local integration (ReDSS 2018). Implementation of the CRRF represents a major shift in Ethiopia's refugee policy. Refugees living in camps will benefit from paid employment. Those in protracted situations will have opportunities to integrate locally and live outside the camps. Jobs will be created for host communities and the government will access international finance and political benefits (Abebe 2018). This is a vital step toward the transition from de facto to de jure right to work for refugees in Ethiopia. It marks the inception of a shift from a camp-based model of refugee assistance to an approach which emphasizes refugee self-reliance, refugee mobility in-country, and the integration of refugees into regional and national development processes (ReDSS 2018). 


\section{KENYA: ACCESS TO WORK FOR URBAN REFUGEES}

Kenya has a long history of hosting large numbers of refugees in the country. By the end of January 2021 , Kenya was host to some 508,033 refugees and asylum seekers. The majority of refugees and asylum seekers are from Somalia (54 percent), followed by the South Sudanese ( 25 percent), Congolese (9 percent), and Ethiopians (6 percent). The remaining refugees are from Burundi, Sudan, Uganda, Eritrea, and Rwanda. Almost half of the refugees in Kenya reside in Dadaab (44 percent), 40 percent in Kakuma, and 16 percent in urban areas, mainly Nairobi (UNHCR 2021c).

\section{A. Legal context}

Until the 1990s, refugee policy favored local integration. The Government of Kenya (GoK) provided limited support, and responsibility for the integration of refugees lay largely with churches and aid organizations. This integration policy was reversed in the early 1990s, when hundreds of thousands of refugees arrived in Kenya fleeing conflict and insecurity in Somalia, Ethiopia, Sudan, Burundi, Rwanda, and the DRC. The scale and profile of the new arrivals prompted a major shift in Kenyan refugee policy away from integration and toward encampment (O'Callaghan and Sturge 2018). The new strategy, the camp option, was deemed the most appropriate by both the Kenyan government and UNHCR because it allowed for the provision of assistance to the large numbers of arriving refugees, while also protecting Kenya's national security interests and facilitating the repatriation of refugees.

Kenya's 2006 Refugees Act stipulated that refugees live in "designated areas," but no areas were officially assigned until the government designated Kakuma and Dadaab in March 2014. This policy was further formalized in 2016 through amendments to 2009 regulations issued under the Refugees Act, specifying that "[a] refugee or an asylum seeker shall be required to reside within a designated refugee camp" and that refugees "who wish to reside outside a designated refugee camp shall apply to the Commissioner for Refugee Affairs for an exemption" (World Bank 2019). A new Refugee Bill was passed through parliament in 2017. Accounts indicate that there may be greater provisions for refugee self-reliance, including the potential for refugees to access land and work permits (O'Callaghan and Sturge 2018).

In Kenya, camp residents in possession of a movement pass can travel to other parts of Kenya. Passes are issued for a limited set of reasons, such as medical or higher educational requirements or protection concerns in camps. Despite the policy of encampment, many urban refugees remain outside camps, with their presence implicitly endorsed by the Kenyan authorities, which have registered some of them in urban areas. In early 2012, the Refugee Consortium of Kenya reported more welcoming procedures for refugees in urban centers than in camps (O'Callaghan and Sturge 2018; Refugee Consortium of Kenya 2012).

The 2006 Refugees Act marked a turning point for the Kenyan government to assume more responsibility in registration and protection. The Act conferred progressive rights to refugees, most notably including reaffirmation of the government's commitment to international refugee conventions; recognition of asylum seekers and refugees along with issuance of a refugee identity card; protection from arbitrary arrest, detention, or expulsion; and recognition of refugee rights to economic and productive activities. The Act stipulates that refugees should be provided with a "refugee identity card." These take the form of either a UNHCR Mandated Refugee Certificate that is valid for two years, or the Department of Refugee Affairs issued Alien Refugee Certificate, valid for five years (UNHCR 2012).

\section{The right to work}

The 2006 Refugees Act provides refugees the same rights to employment as other non-nationals. Employment of non-nationals is governed by the Kenya Citizenship and Immigration Act 2011, under which work permits, called "Class M permits," are granted, usually for two years. Applications for permits also need a recommendation from a prospective employer and must be accompanied by a letter from the authority 
confirming refugee status. While refugees may therefore theoretically work, in practice this is reportedly much more difficult, perhaps partly as a result of Kenya's high unemployment rate of over 39 percent and high dependence on the informal economy. The Refugee Consortium of Kenya stated in 2012 that the government only issues work permits to asylum seekers or refugees in a few isolated cases. Thus, refugees, both skilled and unskilled, seek employment in the informal sector. A thriving informal economy has emerged in the camps, and most refugees in urban centers rely on Kenya's extensive informal economy (O'Callaghan and Sturge 2018).

\section{B. Economic opportunities for camp refugees}

The GoK established the Dadaab and Kakuma refugee camps in the early 1990s to accommodate the influx of refugees. There are now over 400,000 refugees in the camps. The majority of them have been living in the camps (or in other places in Kenya) for more than two decades. In both Dadaab and Kakuma, reliance on humanitarian assistance remains crucial for many refugees, and especially so for new arrivals. Despite restrictions on work, refugees, both skilled and unskilled, are employed by aid organizations in Kakuma and Dadaab, where they are paid "incentives" (rather than full salaries), as well as in the informal sector. An active informal economy, dominated by longer-staying refugees, has emerged in the camps (Betts, Omata, and Sterck 2018; O'Callaghan et al. 2019).

Dadaab refugees have been receiving assistance for over 20 years, and there has been a realization that the orientation of this support needs to change in a manner that will provide more self-sustaining skills to refugees, whether they return to Somalia, stay in Dadaab, or find themselves elsewhere in Kenya or in other countries (Kamau and Fox 2013). Dadaab's refugees are reluctant to leave. The reasons for this vary, but most still feel it is too unsafe to return. Others feel there are more opportunities in Kenya, or simply hold no ties to their "homeland," having been born in the camp (UNHCR 2012). In a study on livelihood activities and opportunities for Dadaab refugees, Kamau and Fox (2013) found that only 2 percent of refugees in Dadaab relied entirely on humanitarian assistance. The study explored economic opportunities for refugees in camps as follows (Kamau and Fox 2013):

- Employment. With regard to employment by the aid agencies, as refugees are not allowed to work in Kenya, it is only possible to hire refugees as "incentive workers," for a fraction of the salary that a Kenyan national would receive in the same post, and the rates are well below the minimum wage. Another source of income is casual work. The refugees who can afford it employ other refugees as laundry workers, or salesperson in their small vegetable and tea kiosks, for very little pay. Overall, difficulty in obtaining work permits limits the opportunities for employment of refugees in Dadaab or elsewhere in Kenya.

- Trade. Trade is big business within the camps. Through their networks in Kenya and back in Somalia, refugee traders are able to source and sell their goods, usually at lower rates than those in other parts of the country. In 2010 there were an estimated 5,000 businesses in Dadaab, ranging from petty traders to large concerns.

- Skills training. In Dadaab, there are a variety of livelihood projects supported by agencies. These include the provision of vocational training and support in areas such as electronics, welding and fabrication, carpentry, tailoring, mechanics, plumbing, tie and dye, weaving, poultry keeping, hairdressing and beauty, soapmaking, and small-scale agricultural activities. Other longer-term support is also provided in the form of literacy and numeracy skills training, information and communication technology skills development, and entrepreneurship skills training. Some of these programs run for a period of one year, others for a few months, with trainees being, on average, between the ages of 15 and 30 years. The emphasis of most projects was found to be on the youth and women. 
In the Kakuma camp, the refugee economy is dynamic: the majority of refugees engaged in economic activities in the camp work for humanitarian agencies, in shops, or in construction, with activities ranging from pharmacies to money transfer companies and breweries. Of those reporting a cash income, the largest source was from employment (36 percent), followed by remittances (29 percent) and business (20 percent). In 2016, Kakuma camp had more than 2,150 shops, including 14 wholesalers (Vemuru et al. 2016).

In both the Dadaab and Kakuma camps, refugees have developed diverse livelihoods. Refugees, while poor, are economically active and doing business with local communities. In terms of income sources of refugees, along with remittances, the main sources of income are employment and income from running a business. Incentive work for aid organizations accounts for approximately 5,000 jobs in Kakuma and an even greater number of jobs in Dadaab. In the Kakuma and Dadaab camps, host markets are dwarfed by refugee markets in terms of size and activity, showcasing the enterprising livelihood strategies that refugees have developed (World Bank 2019).

The refugee camps in Kakuma and Dadaab are located in regions that are relatively underdeveloped, characterized by difficult socioeconomic conditions that include food insecurity, limited access to basic social services and economic infrastructure, and poor livelihood opportunities (World Bank 2019). The economy of those camps is limited. For example, markets in Dadaab that are accessible to refugees do not offer an adequate avenue for the range of products produced by the refugees. The absorption capacity within Dadaab for refugee-made services and products is minimal (Kamau and Fox 2013).

\section{Economic opportunities for non-camp refugees}

Almost one-sixth of asylum seekers and refugees in Kenya live in urban areas, mainly in Nairobi. Refugees in Nairobi are able to access better mobility and public services, but they largely give up access to assistance by coming to urban areas. As a result, they need to be economically independent, with many refugees, particularly men, working. In Nairobi's urban areas, most refugees tend to operate small businesses, find daily casual labor opportunities, and be employed in various retail outlets. Work for casual laborers is widely available and casual labor opportunities are predominantly male activities. Most refugee households seek informal work on a daily basis, and many are low-skilled workers. Petty trade is a common activity among Nairobi's female refugees, and this commonly involves selling food, fruits and vegetables, water, handicrafts, and clothes (UNHCR 2012; World Bank 2019).

Overall, refugees find employment and self-employment opportunities in the highly competitive informal sector. Work permits are not required for casual jobs and refugees accept lower wages in return for work without a background check. The business community is hesitant to engage refugees as a potential market. Without ownership of fixed assets those seeking to start or grow a business fail to meet the collateral requirements to access business loans (UNHCR 2012).

Nairobi's refugees, who have opted to avoid camps for reasons of protection or opportunity, are generally selfreliant and tend to be in a better economic position than those in the camps. Their skills, determination, and resilience have resulted in economic benefits for the host community. However, this does not mean that all urban refugees are wealthy and have achieved full integration into Nairobi's economy. A very low number, estimated at only 2 percent, have a Class $\mathrm{M}$ permit, which allows them to work in the formal economy (Refugee Consortium of Kenya 2015). The few refugees in this position can own their own businesses and make significant profits. The great majority, however, engage in activities below and different to their professional training and competency, and rely on their own means or that of relatives to survive. A recent study showed that refugee incomes were almost equally split between business (29 percent), employment ( 28 percent), and remittances (30 percent), with only 3 percent relying on NGO assistance (O'Callaghan and Sturge 2018; Refugee Consortium of Kenya 2015). 


\section{Integration of refugees}

Kenya's legal and policy environment in relation to refugees is restrictive and dominated by an encampment approach, but the practice often diverges from policy. Despite the encampment approach, at least 16 percent of refugees reside in urban areas. In Kenya, the vast majority of refugees are engaged in economic activities in the informal sector and have made modest gains with limited support from the Kenyan government or the humanitarian community. A minority of urban refugees are successful entrepreneurs providing much social and economic benefit to the communities they reside in. This minority provides a picture of what asylum seekers and refugees can achieve if they are explicitly conferred the right to work and reside in Nairobi, and with that, access to the necessary services and opportunities (Kamau and Fox 2013).

Refugees in the camps remain economically vulnerable, with few assets and limited options for employment. The local integration of camp refugees is difficult to achieve. The Dadaab camp is harsh and remote, limiting the livelihood choices for the refugees. Because of the remote location of the camps and physical curtailment, refugees' socioeconomic opportunities are constrained by their lack of mobility and right to work (O'Callaghan and Sturge 2018).

A scenario involving partial or full integration of Kenya's camp-based refugees appears remote, but there are some indications of a shift in refugee management toward greater self-reliance. Kalobeyei - a dedicated settlement set up to host both refugees and locals - was established in 2015 some $40 \mathrm{~km}$ north-west of the Kakuma camp to promote self-reliance through enhanced service delivery and better livelihood opportunities for 60,000 refugees and 20,000 Kenyans (O'Callaghan et al. 2019). Drawn from examples in Uganda, the GoK is implementing this innovative approach to refugee management with the objective of contributing to the improvement of the socioeconomic conditions of the refugees and host communities and reducing overdependence on humanitarian aid and helping refugees achieve durable solutions. It is a 15-year plan to develop the settlement with greater income-earning opportunities, urban and agricultural and livestock development, integrated service delivery, and private-sector engagement, with the intention for the settlement to eventually become an urban center (O'Callaghan and Sturge 2018).

In comparison with their camp compatriots, refugees in Nairobi enjoy much higher levels of integration due to their ability to draw on their own skills, adaptability, and networks to navigate Nairobi's informal economy and wider socio-political environment. Urban refugees are considered to have achieved a form of de facto integration as they are no longer in physical danger or at risk of refoulement, are not confined to camps or settlements, can sustain a livelihood, are self-sufficient and have similar standards of living to their hosts, have access to public services, and are socially networked into the host community (O'Callaghan and Sturge 2018). 


\section{JORDAN: A MODEL FOR LABOR FORCE INTEGRATION OF REFUGEES}

Since 2011, Jordan has been hosting a substantial number of refugees from Syria. Over 666,000 refugees from Syria are registered with UNHCR in Jordan. Of the 666,294 registered Syrian refugees, only 126,131 live in camps. The breakdown by camp is 78,545 in Zaatari, 40,738 in Azraq, and 6,848 in Mrajeeb al Fhood (UNHCR 2018).

\section{A. Legal context}

The Government of Jordan (GoJ) and international donors have introduced several policy initiatives to address Syrians refugees' long-term residence in Jordan. The cornerstone of these is the integration of refugees into the Jordanian labor force (Hartnett 2019). The GoJ has employed an ambitious approach of labor force integration of refugees to respond to the protracted refugee crisis. This journey had its beginnings in London in February 2016 during the "Supporting Syria and the Region" conference, where the GoJ announced the "Jordan Compact." The Compact called for investments in Jordan that would create jobs and economic opportunities, promote better trade conditions, and support programs that link humanitarian action to development, thus benefiting Jordanians and refugees alike. As noted in the Compact, "Cumulatively these measures could in the coming years provide about 200,000 job opportunities for Syrian refugees while they remain in the country, contributing to the Jordanian economy without competing with Jordanians for jobs." Following the conference, the Jordanian government undertook the necessary administrative changes to allow Syrian refugees to have work permits: the Ministry of Labor (MoL) began issuing one-year renewable work permits in certain occupations open to non-Jordanians, while many administrative requirements were eased (UNHCR 2017). In November 2018, the MoL issued a decision allowing Syrian refugees in Jordan to establish their own home-based businesses (HBBs), in food processing, tailoring, and handicrafts (UNHCR 2019).

\section{Work permits}

Jordan allowed the Syrian refugees to work legally in its labor market and to find employment in "sectors open to immigrants" such as agriculture, construction, services, wholesale trade, and manufacturing in the qualifying industrial zones (QIZs). In July 2016, the European Union (EU) and Jordan also agreed to simplify the "rules of origin" that Jordanian exporters use in their trade with the EU, in return for employing a minimum percentage of Syrian refugees in the QIZs, 15 percent at the outset, increasing to 25 percent in year three (European Training Foundation 2017).

Since the issuance of work permits began, a number of additional steps have contributed to more Syrian refugees working formally. Agricultural cooperatives are allowed to facilitate access to work permits in the sector, and work permits for Syrians remain free of charge. A recent decision of the MoL has also opened the way for refugees in camps to work formally in cities across Jordan; in the Zaatari and Azraq camps, refugees with a valid work permit can leave the camp for up to one month and access available jobs throughout the country (UNHCR 2017).

\section{Home-based businesses}

The number of work permits held by refugee women is still low, although it did increase from 4 percent in 2018 to almost 7 percent in mid-2019. Discussions with women - including the beneficiaries of the UNHCR-funded livelihoods project - continue to indicate a preference for women to work from home. The Cabinet decree in November 2018 allowing Syrian refugees to register and operate HBBs has allowed UNHCR to continue to support the Ministry of Planning and International Cooperation in reaching the home-based businesses "compact" target, which is 100 HBBs licensed and owned by Syrian refugees. Specifically, UNHCR in Jordan aimed to support the establishment of some 80 HBBs by the end of 2019 (UNHCR 2019). 


\section{B. Access to livelihood and employment opportunities}

In Jordan, Syrian refugees now form an important demographic in the labor market, comprising one-fifth of the total non-Jordanian workforce. They have entrepreneurial spirit and valuable skills in specific occupations (UNHCR 2017). To enable Syrian refugees to access employment opportunities, a set of approaches are in place: promoting entrepreneurship, facilitating skills development, providing loans, linking employers with potential employees, and providing information on employment and Jordanian labor rights. As part of this process, a number of small but innovative economic initiatives have been undertaken.

- Assistance for employment preparedness. Since 2017, the Danish Refugee Council and Jordan River Foundation have implemented a livelihood project based on the principle of the graduation approach, whereby individuals who would be rotated out of government cash assistance are identified to be potential beneficiaries. The project aims to improve the livelihoods of the target population and their families through the implementation of small economic projects, by enabling access to available economic opportunities through career guidance, intensive coaching, and sensitizing formal participation in the labor force by obtaining work permits (UNHCR 2019).

- Promoting entrepreneurship. The Danish Refugee Council and Jordan River Foundation started an initiative to support 500 Syrian refugees to find positions with employers, set up their own small businesses, and/or take part in training and apprenticeships. Support through small start-up grants and financial literacy was provided, with the aim of refugee families becoming less dependent on cash assistance and strengthening their assets to successfully graduate toward increased self-reliance (UNHCR 2017).

- Access to credit. UNHCR is partnering with the Swedish Development Agency and Grameen Credit Agricole to promote financial inclusion of refugees for the years 2017-21. This program aims to facilitate access to credit for refugees and host communities, for both income-generating activities and cash-flow smoothing, with the goal of improving livelihoods, self-reliance, and resilience of the target population (UNHCR 2017).

- Camp employment centers. The Zaatari Employment Office and Azraq Center for Employment are part of a unique UNHCR and ILO initiative to increase mobility of camp residents and to provide employment information. Established inside the two refugee camps, the offices allowed refugees to receive counseling services on employment, obtain work permits, and attend job fairs where they can meet employers (UNHCR 2017; UNHCR 2019).

- Support for artisanal work. A small group of Syrian refugee women with experience in sewing and tailoring are trained by SEP Jordan, a fashion business, in the Jerash Palestinian Camp. The pilot project's objective is to introduce the trainees into the SEP workforce as freelancers and encourage interaction with Palestinian refugees who have been settled in Jordan for 50 years as well as facilitate economic empowerment (UNHCR 2017).

- Cash for work. The cash-for-work scheme (also called Incentive-Based Volunteering) is an important tool for short-term employment in the camps and an important cash injection in the camps' economy. In addition, it helps refugees gain work experience in selected sectors. Each month 6,500 refugees in the Zataari camp and over 1,700 in the Azraq camp have a temporary occupation; they are recruited as volunteers by many humanitarian organizations with an active presence in the camps (UNHCR 2017). Cash-for-work schemes have been operating in many of Jordan's Syrian refugee camps since their establishment, but more recently these activities have been rolled out to non-camp spaces as 
well. Besides, since 2017 attempts have been made to translate cash-for-work-based employment into work permits.

- Skills training. The Migrant Support Measures from an Employment and Skills Perspective project is implementing interventions on formal and nonformal training of refugees. Most initiatives focus on skills development, including life skills, soft skills, financial and market literacy, and language skills for young people and vulnerable groups, as well as children who cannot continue in the formal education system. However, most of the initiatives focus on only one type of intervention and do not combine different measures in a single package (European Training Foundation 2017).

\section{Integration of refugees}

The GoJ's initiatives and measures since early 2016 have sought to facilitate Syrian refugees' access to the formal labor market. The plan is intended to address both humanitarian obligations toward Syrian refugees and Jordan's economic development needs. Three strategies are in place to make the Jordan Compact happen - the expansion, substitution, and formalization of employment (Lenner and Turner 2019).

- First, the plan is to employ refugees in special economic zones and to boost Jordan's economy by attracting foreign investments through trade concessions.

- Second, there are attempts to replace migrant workers with Syrians. This strategy is based on twin goals of bringing Syrians into formal jobs and creating employment for Jordanians.

- Third, there are attempts to formalize Syrian refugee labor. The number of work permits issued to Syrians, as a result of strong pressure from some donor agencies, quickly became a core indicator of the scheme's success.

Refugee labor integration does not harm the host country labor force. In Jordan, this is because refugees and citizens are not competing for the same jobs. The Jordanian government has prioritized issuing formal work permits for Syrian refugees in sectors that Jordanians prefer to avoid, including agriculture, manufacturing, and construction. Historically, these sectors have been dominated by migrant laborers, primarily Egyptians. Syrian refugees are displacing other migrant groups in these sectors. The Jordan Compact's implicit intention of prioritizing Jordanian labor has been successful, at least insofar as jobs have not been taken away from Jordanian workers (Hartnett 2019). 


\section{MALAYSIA: NO RIGHT FOR REFUGEES TO WORK}

According to the UNHCR, as of March 2020, there were 179,520 registered refugees and asylum seekers from various countries in Malaysia. Some 154,460 are from Myanmar, comprising 101,580 Rohingyas, and 52,880 other ethnic groups from Myanmar. There are 25,050 refugees and asylum seekers from other countries, including Pakistan, Yemen, Somalia, Syria, Afghanistan, Sri Lanka, Iraq, and Palestine. Some 68 percent of refugees and asylum seekers are men, while 32 percent are women (UNHCR 2020a). In Malaysia, the Rohingya population consists of a mix of new arrivals and first- and second-generation refugees living in protracted displacement. Most are stateless because Myanmar's 1982 Citizenship Law denies them the right to citizenship, and refugees born in Malaysia are not granted Malaysian citizenship (Wake 2016).

\section{A. Legal context}

Malaysia is not a signatory to the UN Convention on Refugees. The country has no legal or administrative framework for dealing with refugees (Jalil 2019). Malaysia, on humanitarian grounds, generally allows asylum seekers and refugees to stay in the country. Although refugees are not recognized in national law or policy, they are allowed to live in local communities once registered. The vast majority of Rohingyas are unable to obtain a passport or citizenship document in Myanmar and arrive in Malaysia with a Myanmar identity document or no documents at all. The primary (and often only) identity document used by Rohingya refugees in Malaysia is a UNHCR card (Wake 2016).

In Malaysia, refugees lead a precarious existence on the margins of society, at risk for arrest as illegal immigrants, since Malaysia makes no distinction between undocumented or illegal workers and refugees. A majority of them live in urban areas and have no right to work (Ahmad, Rahim, and Mohamed 2016). With no legal status, refugees are denied access to safe and lawful employment and equal protection of the law and are vulnerable to arrest, detention, deportation, and exploitation if found working (Brown et al. 2018b).

\section{Access to public services}

Since refugees in Malaysia do not qualify for a legal status, their entitlement to public services is minimal. UNHCR-registered refugees and asylum seekers are not entitled to government-funded social security. Refugees in Malaysia are also not entitled to access the public school system. Some limited education is provided instead through an informal parallel system of community-based learning centers. These centers are administered by NGOs, charities, and the refugee community and are reliant on fundraising and international aid. UNHCR currently has five implementing partners in the education sector that operate learning centers and coordinate projects such as teacher training and teachers' compensation. As a result of limited education provision, only 33 percent of refugee children of schoolgoing age are enrolled in community learning centers (Todd, Amirullah, and Shin 2019).

\section{B. Access to livelihood and employment}

In Malaysia, many local Malaysians regularly interact with refugees. In Kuala Lumpur, Rohingya refugees live in pockets across the city: neighborhoods are mixed, comprising local Malaysians, immigrants, Rohingya refugees, and refugees from various parts of the world. Malaysians have assisted refugees by supporting their livelihoods (e.g., employing refugees or helping them secure jobs; providing investment capital for refugees' businesses); overcoming bureaucratic restrictions (e.g., purchasing goods for refugees that they are prohibited from buying themselves, such as motorcycles); facilitating their access to institutions (e.g., UNHCR); and providing direct assistance (e.g., donations of cash and goods). Many refugees appreciated that Malaysians sympathize or empathize with their plight (Wake and Cheung 2016).

Malaysia is a very restrictive environment for NGOs. Few international NGOs are able to register in Malaysia. With limited NGO and state involvement, UNHCR has become the most prominent and influential formal 
institution in refugees' lives, serving not only as the gatekeeper to registration and resettlement, but also the most visible potential provider of financial, livelihoods, protection, and health support (Wake and Cheung 2016).

As in many countries, in Malaysia the topic of foreign workers is contentious, and refugees are often conflated into the same category as undocumented or foreign workers. In the early 1990s, when large numbers of Rohingya refugees first started coming to Malaysia, the government provided some with six-month work permits; these were nonrenewable, however, and since then no work permit schemes for refugees have been successfully implemented. Previous efforts to regularize the status of the Rohingya have failed amidst accusations of fraud and corruption, including an attempt in 2006 to issue IMM13 permits (a type of temporary residence permit that the Minister of Immigration can authorize at their discretion) to Rohingya refugees. UNHCR has increasingly advocated for work permits for refugees in Malaysia (UNHCR 2016). In recent years the Malaysian government has considered - and in numerous instances initiated the process of issuing work permits to refugees; most recently, a high-level government committee was formed to consider the issue (Wake 2016; Lokman 2016).

In 2013, the Malaysian government announced it would provide refugees with work permits. However, implementation has been slow. Though a pilot is underway to allow refugees to work legally, the project is only open to Rohingya refugees who are cardholders and who have undergone health and security screenings. Furthermore, employment opportunities are restrictive, with applicants placed in manufacturing or plantation industries with no choice of employment themselves (Brown et al. 2018b).

Despite not having the legal right to work, many of the refugees and asylum seekers in Malaysia are engaged in informal employment. This is unsurprising, given that refugees receive no welfare from the government, and foreign aid and NGO support is insufficient to cover basic needs. The sectors that refugees and asylum seekers are employed in is largely dictated by what is available to those working illegally, often including dirty, dangerous, and difficult ("3D") jobs. There are likely to be very few skilled jobs available in the informal labor market, and therefore refugees and asylum seekers possessing higher skill levels will be unable to put these to full use. Not all adult refugees and asylum seekers are informally employed. Based on the UNHCR statistics, the labor participation rates among refugees and asylum seekers are lower than for the population as a whole. Overall, the labor participation rate of UNHCR registered Rohingya refugees is 58 percent: 65 percent among males and 29 percent among females (Todd, Amirullah, and Shin 2019).

\section{Integration of refugees}

The stance of the Government of Malaysia (GoM) toward refugees is, on the one hand, one of tacit and limited acceptance, and on the other formal abdication of any responsibility for responding to the needs of people seeking asylum in Malaysia. The formal response has ostensibly been delegated to UNHCR, whose work is simultaneously made more difficult by state policies (such as detention) aimed at deterrence and exclusion, and the hostility of the state toward the notion of Malaysia as a final destination country for refugees (Wake 2016; Lokman 2016).

The current position is that refugees are not allowed to work lawfully in Malaysia, and few receive assistance. In a study by the International Rescue Committee, 92 percent of refugee respondents said that neither they nor a member of their household had received humanitarian aid or services during the previous year (Smith 2012). Refugees often resort to working "3D" jobs in the informal sector, and the illegality of their status renders them at increased risk of exploitation by employers (Wake 2016).

In Malaysia, many refugees are already working informally. However, refugees' participation rate in the labor force is lower than the national average, which is in part a result of the dangerous and unattractive nature of the work available, including the fact that refugees and asylums seekers are vulnerable to arrest and detention as they are working illegally (Todd, Amirullah, and Shin 2019). 
UNHCR in Malaysia works with the objective of facilitating refugees' right to work and to establish strong, representative refugee community-based organizations toward self-reliance. They work with local institutions, social enterprises, and NGOs to provide livelihood and development assistance to individuals and communities of concern (UNHCR 2020b). UNHCR has proposed the legal right to work, which would enable refugees to accumulate social and capital resources, which could help them find a solution appropriate for their unique circumstances. The GoM has implemented several work permit schemes for small, select groups of refugees, but so far its policies are ad hoc (Jalil 2019).

In Malaysia, the reality is that local integration is the most likely durable solution for many Rohingya refugees. While Malaysian policy does not support local integration of refugees, many have achieved some degree of informal integration: most Rohingya refugees work in the informal sector, rent accommodations, access health care at government facilities, and pray at Malaysian mosques. Yet many refugees spend years, decades, and even generations living in limbo, lacking the prospect of a formal durable solution (local integration, resettlement, or repatriation) (Wake 2016). In the absence of strong political will of the government, refugees in Malaysia can only be informally integrated into the economy and community, with no future for themselves and the generation to come. 


\section{Discussion}

Local integration is generally regarded as a process which leads to a durable solution for refugees. The local integration of refugees starts with a legal process, whereby refugees are granted a progressively wider range of rights and entitlements by the host country. National and local refugee policies, including laws and frameworks, are an important determinant in the extent to which refugees can achieve self-reliance in host countries (Brown et al. 2018b). Refugee integration is determined by the conditions and environment in which their settlement occurs. In an enabling context, refugees become self-reliant through employment or selfemployment. However, legal opportunities for refugees to work vary significantly across host countries. The following discussion highlights the ways in which national policies and initiatives on refugee integration vary across five countries: Uganda, Ethiopia, Kenya, Jordan, and Malaysia. This section also explores the situation of refugees' right to work, for both de jure and de facto ${ }^{3}$ right to work.

\section{REFUGEE RIGHT TO WORK}

Uganda's approach is noted as a model for refugee-hosting countries around the world due to its progressive legislation granted by the 2006 Refugee Act and the Refugee Regulations 2010. In Uganda, refugees are granted a wider range of rights and entitlements, including a legal right to work, freedom of movement, and access to services such as education and health. Uganda uses an open settlement policy: it allows refugees plots of land for residence and cultivation of crops and promotes freedom of movement for refugees to realize opportunities, notably in education and income-generation, not restricted to the settlement.

Ethiopia follows encampment practices, but refugees can leave the camp with a permit to access specific services. Refugees can live outside the camp under conditions of out-of-camp policy, specialist healthcare needs, and serious protection concerns. Refugees are generally not allowed to work in Ethiopia, but there are no legal restrictions on informal work. Ethiopia pursued restrictive labor policies for refugees in their country until the introduction of the CRRF approach on local integration of refugees in 2017. Under this framework, there is a provision of work permits to qualifying refugees and a fixed percentage of jobs within industrial parks. Moreover, refugees living in protracted situations will have opportunities to integrate locally and live outside camps.

In Kenya, refugees lack freedom of movement because of its policy of encampment. Camp residents in possession of a movement pass can only travel to other parts of Kenya. Refugees are in general not allowed to work formally. The Refugee Act of 2006 provides refugees the same right to employment as other nonnationals and allows them to have work permits. Refugees have the option to obtain work permits usually for two years as permissible to non-nationals. Applications for permits need a recommendation from a prospective employer and must be accompanied by a letter from the relevant government authority confirming refugee status. In fact, difficulties in securing work permits restrict the work prospects of refugees in Kenya.

Since 2016, the Jordanian government has allowed both urban refugees and those refugees in the camps a legal right to work. The government allows refugees to have work permits in certain occupations open to immigrants/non-Jordanians. Camp refugees are allowed to work outside the camp which is conditional upon securing legal permission to leave. Agricultural cooperatives allow free-of-charge work permits for Syrian refugees. In November 2018, the Jordanian government issued a decision allowing Syrian refugees to establish their own home-based businesses in food processing, tailoring, and handicrafts.

Malaysia is not a signatory to the UN Convention on Refugees. The country has no legal or administrative framework for dealing with refugees. Malaysia, on humanitarian grounds, generally allows asylum seekers and

3 De jure rights are those recognized by official laws, while de facto rights exist and are accepted in practice but do not have legal status. 
refugees to stay in the country. Refugees can live in local communities once registered. The current position is that refugees are not allowed to work lawfully in Malaysia, and few receive assistance. The government has implemented several work permit schemes for small, select groups of refugees, but so far its policies are ad hoc.

To understand the situation of these five host countries in terms of granting work rights to refugees, five typologies were used: (A) right to work in action, (B) right to work in progress, (C) restricted right to work, (D) no right but allowed in practice, and (E) no right and restricted in practice. As shown in Table 1, none of these five countries falls under Category A whereby the right to work is enforced and international standards are incorporated into a fully functioning domestic policy without reservation. Among the study countries, the most favorable condition for refugees' right to work is observed in Uganda (Category B). Uganda has a national policy and well-defined framework permitting refugees to work. In Jordan and Kenya, a certain proportion of refugees are allowed to work in strictly defined sectors and occupations (Category $\mathrm{C}$ ). In Ethiopia refugees are not allowed to work, but there are no legal restrictions on informal work (Category D). Malaysia represents Category $\mathrm{E}$, the most restrictive in terms of granting work rights to refugees.

Table 1: Refugee right to work in five host countries

\begin{tabular}{|l|l|l|l|}
\hline Rank & Typology & Definition* & Countries \\
\hline Category A & $\begin{array}{l}\text { Right to work } \\
\text { in action }\end{array}$ & $\begin{array}{l}\text { Where the right to work is enforced. International standards are } \\
\text { incorporated into a fully functioning domestic policy without reservation, } \\
\text { and refugees' right to work is explicitly cemented in national legislation. }\end{array}$ & None \\
\hline Category B & $\begin{array}{l}\text { Right to work } \\
\text { in progress }\end{array}$ & $\begin{array}{l}\text { Where there is a national policy permitting refugee right to work but it is not } \\
\text { entirely enacted and legal constraints remain. }\end{array}$ & Uganda \\
\hline Category C & $\begin{array}{l}\text { Restricted } \\
\text { right to work }\end{array}$ & $\begin{array}{l}\text { Where there are severe legislative restrictions on formal refugee work that } \\
\text { may exclude certain groups. There may or may not be a national policy on } \\
\text { the right to work for refugees. }\end{array}$ & $\begin{array}{l}\text { Jordan } \\
\text { Kenya }\end{array}$ \\
\hline Category D & $\begin{array}{l}\text { No right but } \\
\text { allowed in } \\
\text { practice }\end{array}$ & $\begin{array}{l}\text { Where there is no existing national policy that respects refugees' right to } \\
\text { work or the national policy prohibits refugees from working, but there are } \\
\text { no punitive legal restrictions from government or local authorities on most } \\
\text { informal work. }\end{array}$ & Ethiopia \\
\hline $\begin{array}{l}\text { Category E } \\
\text { Noright and } \\
\text { restricted in } \\
\text { practice }\end{array}$ & $\begin{array}{l}\text { Where there is no existing national policy that respects refugees' right to } \\
\text { work or the national policy prohibits refugees from working and this is } \\
\text { heavily policed. }\end{array}$ & Malaysia \\
\hline
\end{tabular}

*Adapted from: Brown, Alison, Peter Mackie, Kate Dickenson, and Tegegne Gebre-Egziabher. 2018. "Urban refugee economies: Addis Ababa, Ethiopia." London: International Institute for Environment and Development.

\section{ECONOMIC OPPORTUNITIES FOR REFUGEES}

In Uganda, economic opportunities such as employment (formal and informal) and access to productive capital are available for refugees, but they are not the same in rural and urban areas. In rural settlements, refugees are primarily engaged in agricultural activities. Not many opportunities besides agriculture exist. The primary non-agricultural income-generating activities for refugees and Ugandans are small business or petty trade. Refugees who have self-settled in urban areas are engaged in various types of small businesses. Some are engaged in entrepreneurial activities aiming to scale businesses where they can employ others. Refugees have higher income and lower dependency levels in the city compared with the camp context.

Historically, the Ethiopian government enforced a restrictive encampment policy for refugees, barring refugee access to work and mobility. In camps, refugees mostly survive on humanitarian assistance. Some are engaged in economic activity within the camp or in the neighboring host markets. Refugees have access to incentive work of local NGOs and UN agencies, are engaged informally in employment, and carry out informal 
trade with host communities. However, the isolation of the camps coupled with restrictions on access to labor markets and employment resulted in a challenging environment for sustainable livelihoods for refugees. On the other hand, refugees settled in urban areas become progressively integrated there in economic and social terms. A wide number of refugees have been involved in Ethiopian-owned and refugee-owned informal enterprises, hospitality business, construction, service provision, and work as casual day laborers, electricians, and mechanics.

Similar to Ethiopia, the Kenyan government started to enforce a restrictive encampment policy for refugees in the early 1990s. Economic opportunities are limited for refugees inside the camp and host communities. The refugee camps in Dadaab and Kakuma are located in relatively underdeveloped regions, with vulnerable economies. The majority of refugees are engaged in the camp work for humanitarian agencies (known as incentive work), in shops, or in construction. Refugees are also engaged in self-employed enterprises. Trade in camps is a huge business. Due to the remote location of the camps and physical curtailment, refugees' socioeconomic opportunities are constrained by their lack of mobility and right to work. In contrast, some refugees outside the camps have become self-reliant through employment in Nairobi's thriving informal sector and are able to access some health and educational services. Almost one-sixth of asylum seekers and refugees in Kenya live in urban areas, mainly in Nairobi. Refugees find employment and self-employment opportunities in the highly competitive informal sector. Among urban refugees, a few are successful entrepreneurs.

Jordan allows the Syrian refugees legal work permits in the labor market and employment opportunities in designated sectors open to immigrants. Jordanian exporters can enjoy trade benefits from European Union countries in return for employing a minimum percentage of Syrian refugees. Syrian refugees living outside the camps primarily work in construction, wholesale, retail and repair trades, agriculture, and manufacturing in special economic zones. They often undertake entrepreneurial activities and have valuable skills in specific occupations. They now form an important demographic in the labor market, comprising one-fifth of the total non-Jordanian workforce.

The Malaysian government has pledged to provide refugees with work permits. However, implementation has been slow. Employment opportunities are restrictive, with applicants placed in manufacturing or plantation industries with no choice of employment themselves. Despite not having the legal right to work, many of the refugees and asylum seekers are engaged in informal employment, particularly "3D" jobs (jobs that are dangerous, dirty, and difficult). Refugees are vulnerable to arrest and detention as they are working illegally.

Table 2: Economic inclusion of refugees in five host countries

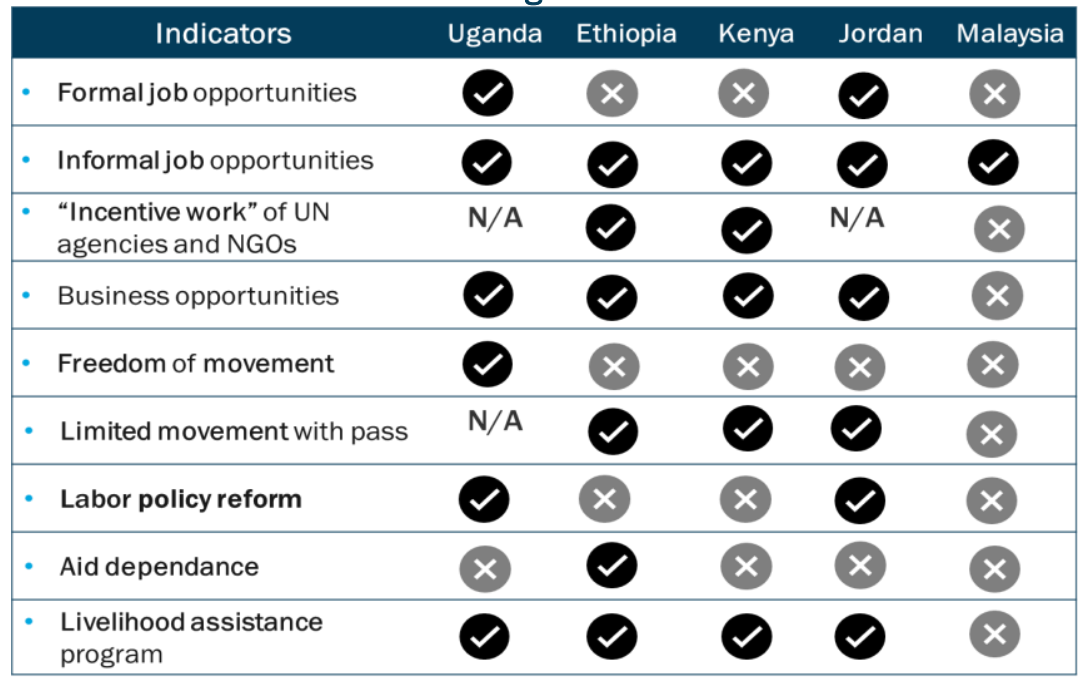




\section{INTEGRATION OF REFUGEES}

Uganda has a long history as a host country for refugees, and the integration of refugees into Ugandan society has been a common occurrence. The legal structures of Uganda have shaped, and continue to shape, the possibilities for local integration in this country. In Uganda, refugees are allowed to engage in both agricultural and a wide variety of non-agricultural economic activities. Most importantly, refugees are given plots of residential and agricultural land. The local population provides land for refugee settlement in exchange for schools and health centers in the host community. Integrated services to refugee-hosting areas are now provided to ensure that refugees and host communities benefit from shared, rather than parallel, services. Refugees living outside the settlement can live and buy property as permissible to any foreign nationals. Since 2016, Uganda has started to integrate refugee programming into the national development plan.

Ethiopia's refugee policy requires refugees to live in camps, with the exception of a small number of people who are allowed to stay in urban centers because of special protection concerns or health needs. In addition, since 2010 many more have been given the option of living outside the refugee camps as part of the government's out-of-camp policy. Refugees are entitled to engage only in informal income-generating activities. Recently, the government of Ethiopia has been in the process of adopting a framework, similar to that of Uganda, on local integration of refugees. In particular, the government has made pledges to shift from a campbased model of refugee assistance to an approach which emphasizes refugee self-reliance and refugee mobility in-country.

Jordan has gained a reputation for its initiatives on labor force integration of refugees as a durable solution. The government's initiatives and measures since 2016 have sought to facilitate Syrian refugees' access to the formal labor market. Key strategies for labor force integration of refugees include the provision of work permits to formalize employment of refugees and the employment of refugees in special economic zones to boost the economy by attracting foreign investments. In parallel, the process also included: implementation of small economic projects, access to available economic opportunities through career guidance, skills training, and apprenticeships. Livelihood assistance programs are in place to provide financial literacy and awareness trainings and provide support for business set-up by arranging work permits, small start-up grants, and credits.

In Kenya, the integration of camp refugees is hard to realize due to its policy of encampment and the remote location of camps. However, urban refugees enjoy much higher levels of integration than camp refugees as they are not confined to camps, can obtain work permits, can find economic opportunities in the formal sector, have access to public services, and are socially networked into the host community. But this does not indicate that every urban refugee is affluent and has completely integrated into the economy of Nairobi.

Malaysian policy does not support economic integration of refugees. There are no policies and initiatives that promote refugees' right to work. 


\section{Conclusion}

Economic integration of refugees is determined by the conditions and policy environment in which their settlement occurs. The integration starts with granting the legal right to work. The right to work primarily entails access to labor markets, business, entrepreneurship, and economic opportunities. UNHCR has identified other close or related enabling rights, such as freedom of movement, housing, land, education, and property rights, or access to relevant resources and services, such as financial services, training, social protection, or employment and business registration, which can effectively support refugees to fully enjoy the right to work.

There are notable differences in the level and extent of economic integration of refugees across host countries. In Uganda and Jordan, refugees have legal access to work. Uganda provides a unique example of refugee integration as it has granted a wide range of rights and entitlements for refugees, including access to work in the formal economy, freedom of movement, access to land for residence and cultivation, and access to the health, education, and agricultural extension services similar to those of Ugandans. Refugees are not confined to camps but can live in urban areas and buy property as permissible to any foreign nationals. Uganda provides an important foundation in terms of the legal infrastructure to allow many refugees to lead independent lives.

Comparatively, Uganda's neighbors -- Kenya and Ethiopia -- have traditionally been more restrictive. Both Kenya and Ethiopia rely on a system of encampment, where most refugees live in camps. In Kenya and Ethiopia, refugees enjoy a limited right to work. Refugees can access informal work but their access to formal work is restricted and well defined. In Kenya, some elements for de facto integration exist for urban refugees as they can access better mobility and health and educational services, obtain work permits, access employment and business, and are socially networked into the host community. Ethiopia is an important case study on refugee economic inclusion. Historically, the Ethiopian government enforced a restrictive encampment policy for refugees and only very recently has local integration of refugees become a possibility. The provision of work permits to qualifying refugees, jobs within industrial parks, and access to irrigable land are notable efforts in progress for economic integration of refugees, however, the country has a long way to go to fully implement these policies.

Jordan is more progressive toward refugees than Ethiopia and Kenya. The Jordanian government has taken an unprecedented legal step to support integration of Syrian refugees in its labor force. Jordan not only provides work and business permits and employs refugees in special economic zones, but also provides access to a wide range of support services including education, skills training, apprenticeship, finance, and job placement services. Malaysian policy does not support economic integration of refugees and there is an absence of progressive policies and initiatives that promote refugee access to work.

The national policies and initiatives of host countries define the extent of economic inclusion of refugees. A comparison of the situation on the legal right to work reveals highly favorable conditions for refugee rights in Uganda among these five host countries. Uganda has a national policy and well-defined framework permitting refugees to work. In Jordan and Kenya, a certain proportion of refugees are allowed to work in strictly defined sectors and occupations. In Ethiopia, refugees are not allowed to work in the formal economy, but there are no legal restrictions on informal work. The Ethiopian government is now focusing on measures to extend refugee rights and relax its camp-based approach. Malaysia is found to be most restrictive in terms of granting work rights to refugees.

Of the five refugee-hosting countries, Malaysia is the most restrictive and least progressive in integrating refugees locally. Ethiopia is the next most restrictive host country in terms of refugee integration. In host countries like Ethiopia with no existing national policy that respects refugees' right to work, but no legal restrictions on informal work, the potential for inclusion of refugees in the formal economy is high. In host countries like Malaysia, where national policy prohibits refugees from working, there is no alternative than to 
facilitate policy development to grant refugees the right to work. Advocacy efforts should build on the evidence base demonstrating the potential and the positive impact that economic inclusion can have on refugees and host communities.

The analysis of local integration of refugees has important implications for host countries regarding the provision of employment and work opportunities for refugees. However, there are notable differences in the economy and labor market by countries. None of the five countries belongs to the high-income economies. Uganda and Ethiopia are low-income countries, Kenya lower-middle income, and Jordan and Malaysia uppermiddle income. In the three African countries, the labor market is mostly informal while labor markets in Malaysia and Jordan are largely formalized. In general, urban refugees enjoy greater agency as they are generally more mobile, resourceful, and socially connected when compared with camp-based refugees. The review also found the Ugandan model and Jordanian approach worthy of being replicated in socioeconomically comparable host countries. Uganda's refugee legislature and policy are known worldwide, and Ethiopia to some extent has begun to apply similar measures as both these countries have similar socioeconomic contexts. Jordan's initiative to integrate Syrian refugees into the labor market may be a suitable measure for upper-middle income countries like Malaysia with a more formalized labor market. Yet, the predetermined model or framework should not be readily adopted in situations of protracted displacement without examining the legal, economic, and socio-cultural realities specific to the refugee context. 


\section{References}

Abebe, Tsion Tadesse. 2018. “Ethiopia's Refugee Response: Focus on Socio-Economic Integration and SelfReliance." Pretoria: Institute for Security Studies. Available at: https://issafrica.s3.amazonaws.com/site/uploads/ear19.pdf.

Ahmad, Abdullahi Ayoade, Zulkanain Abdul Rahim, and Abdul Majid Hafiz Bin Mohamed. 2016. "The refugee crisis in Southeast Asia: The Malaysian experience," International Journal of Novel Research in Humanity and Social Sciences, 3(6): 80-90.

Bern, Rachel. 2016. "Uganda - Local Integration Focus: Durable Solutions Framework Overview - Key Achievements and Remaining Gaps." Nairobi: Danish Refugee Council, Regional Durable Solutions Secretariat (ReDSS). Available at: http://regionaldss.org/wp-content/uploads/2017/11/ReDSS-Solutions-FrameworkUganda-local-integration-focus-2016.pdf.

Betts, A., L. Bloom, J. Kaplan, and N. Omata. 2014. "Refugee Economies: Rethinking Popular Assumptions." Oxford: University of Oxford, Refugee Studies Center. Available at: https://www.rsc.ox.ac.uk/files/publications/other/refugee-economies-2014.pdf.

Betts, Alexander, Naohiko Omata, and Louise Bloom. 2017. "Thrive or survive? Explaining variation in economic outcomes for refugees," Journal on Migration and Human Security 5(4): 716-743. Available at: https://journals.sagepub.com/doi/pdf/10.1177/233150241700500401.

Betts, Alexander, Naohiko Omata, and Olivier Sterck. 2018. "Refugee Economies in Kenya." Oxford: Refugee Studies Center. Available at: www.rsc.ox.ac.uk/publications/refugeeeconomies-in-kenya.

Bohnet, H. and C. Schmitz-Pranghe. 2019. “Uganda: A role model for refugee integration?” BICC Working Paper 2/2019. Bonn: Bonn International Center for Conversion (BICC). Available at: https://www.bicc.de/uploads/tx_bicctools/WP2_19_Uganda_web.pdf.

Brown, Alison, Peter Mackie, Kate Dickenson and Tegegne Gebre-Egziabher. 2017. "Refugee economies: Lessons from Addis Ababa." London: International Institute for Environment and Development (IIED). Available at: https://pubs.iied.org/pdfs/17445IIED.pdf.

Brown, Alison, Peter Mackie, Kate Dickenson and Tegegne Gebre-Egziabher. 2018a. "Refugee livelihoods in the international context, Ethiopia." London: International Institute for Environment and Development.

Brown, Alison, Peter Mackie, Kate Dickenson, and Tegegne Gebre-Egziabher. 2018b. “Urban refugee economies: Addis Ababa, Ethiopia." London: International Institute for Environment and Development.

Crisp, Jeff. 2003." No solution in sight: The problem of protracted refugee situations in Africa." New Issues in Refugee Research, Working Paper No. 75. Geneva, Switzerland: UNHCR.

Crisp, Jeff. 2004. "The local integration and local settlement of refugees: A conceptual and historical analysis." Working Paper No. 102. Geneva, Switzerland: Evaluation and Policy Analysis Unit, UNHCR.

Dryden-Peterson, Sarah and Lucy Hovil. 2004. "A remaining hope for durable solutions: Local integration of refugees and their hosts in the case of Uganda," Refuge: Canada's Journal on Refugees 22(1): 26-38.

Available at: https://refuge.journals.yorku.ca/index.php/refuge/article/view/21315.

European Training Foundation. 2017. "Migrant Support Measures from an Employment and Skills Perspective (MISMES) - Jordan." Turin: European Training Foundation. Available at:

https://www.etf.europa.eu/sites/default/files/m/FE1739179121898CC12581F5004EBD48 MISMES\%20Jor dan.pdf.

Government of Uganda, UNHCR, and World Bank. 2016. “An Assessment of Uganda's Progressive Approach to Refugee Management." Washington, DC: World Bank. Available at: https://openknowledge.worldbank.org/bitstream/handle/10986/24736/AnOassessment00oOrefugeeOmana gement.pdf?sequence=1\&isAllowed $=\mathrm{y}$. 
Graham, Jimmy and Sarah Miller. 2021. "From Displacement to Development: How Ethiopia Can Create Shared Growth by Facilitating Economic Inclusion for Refugees." Washington, DC: Center for Global Development \& Refugees International.

Hartnett, Allison Spencer. 2019. "The effect of refugee integration on migrant labor in Jordan," Review of Middle East Studies 52(2), 263-282. Available at: https://data2.unhcr.org/en/documents/download/67857.

Jalil, Aslam Abd. 2019. "The Right to Work can Empower Refugees in Malaysia." Waltham, MA: The Conversation U.S. Available at: https://theconversation.com/the-right-to-work-can-empower-refugees-inmalaysia-119666.

Kamau, Christine and John Fox. 2013. "The Dadaab Dilemma: A Study on Livelihood Activities and Opportunities for Dadaab Refugees." Nairobi: Danish Refugee Council (DRC) and UNHCR. Available at: https://www.alnap.org/help-library/the-dadaab-dilemma-a-study-on-livelihood-activities-and-opportunities-fordadaab.

Lenner, Katharina and Lewis Turner. 2019. "Making refugees work? The politics of integrating Syrian refugees into the labor market in Jordan," Middle East Critique 28(1): 65-95. DOI: 10.1080/19436149.2018.1462601

Lokman, T. 2016. "Nur Jazlan warns UNHCR: Do not blackmail Malaysia," New Straits Times. Kuala Lumpur. Available at: http:// www.nst.com.my/news/2016/06/153628/nur-jazlan-warns-unhcr-do-not-blackmailmalaysia.

Mathys, Ellen. 2016. "Opportunities to Provide Refugees and Ugandans with Alternative Livelihood Activities in Uganda's Kamwenge District." Washington, DC: FHI 360/FANTA.

Milner, James and Gil Loescher. 2011. "Responding to protracted refugee situations: Lessons from a decade of discussion." Forced Migration Policy Briefing 6. Oxford: Refugee Studies Center, Oxford Department of International Development, University of Oxford.

O'Callaghan, Sorcha and Georgina Sturge. 2018. “Against the Odds: Refugee Integration in Kenya." London: Humanitarian Policy Group, Overseas Development Institute.

O'Callaghan, Sorcha, Farah Manji, Kerrie Holloway, and Christina Lowe. 2019. “The Comprehensive Refugee Response Framework Progress in Kenya." HPG Working Paper. London: Overseas Development Institute.

Refugee Consortium of Kenya (RCK). 2012. "Asylum Under Threat: Assessing the Protection of Somali Refugees in Dadaab Refugee Camps and Along the Migration Corridor." Nairobi: RCK. Available at: https://reliefweb.int/sites/reliefweb.int/files/resources/Asylum Under Threat.pdf.

2015. "Myths and Truths, Livelihoods in Nairobi: The Facts About Refugee Self-Sufficiency and Economic Contribution in Nairobi." Nairobi: RCK.

Regional Durable Solutions Secretariat (ReDSS). 2018. "Local Integration Focus - Refugees in Ethiopia: Gaps and Opportunities for Refugees Who Have Lived in Ethiopia for 20 Years or More." Nairobi: Danish Refugee Council.

Smith, A. 2012. "In Search of Survival and Sanctuary in the City: Refugees from Myanmar/Burma in Kuala Lumpur, Malaysia." New York: International Rescue Committee.

Todd, Laurence, Adli Amirullah, and Wan Ya Shin. 2019. "The economic impact of granting refugees in Malaysia the right to work," Policy Ideas No. 60. Available at: https://www.tent.org/wpcontent/uploads/2019/08/IDEAS-Malaysia.pdf.

UNHCR. 2012. "Promoting Livelihoods to Build the Self-Reliance of Urban Refugees in Nairobi." Kenya: UNHCR.

2016. “UNHCR Rolls Out New Card." Geneva: UNHCR. Available at:

http://www.unhcr.org.my/News_Views-@-NHCRMalaysiaNewCard.aspx.

. 2017. "Refugee Livelihood - Jordan." Geneva: UNHCR. Available at:

https://data2.unhcr.org/en/documents/download/60230. 
2018. Jordan Fact Sheet. Geneva: UNHCR. Available at:

https://data2.unhcr.org/en/documents/details/64114.

. 2019. "Livelihood Opportunities for Refugees - Jordan." Geneva; UNHCR. Available at:

https://reliefweb.int/sites/reliefweb.int/files/resources/70513.pdf.

2020a. Figures at a Glance in Malaysia. Geneva: UNHCR. Available at: https://www.unhcr.org/figures-at-aglance-in-malaysia.html.

__. 2020b. "Livelihoods in Malaysia." Geneva: UNHCR. https://www.unhcr.org/livelihoods-in-malaysia.html.

__. 2021a. "UNHCR Operational Data Portal - Uganda." Geneva: UNHCR. Available at:

https://data2.unhcr.org/en/country/uga.

__. 2021b. “UNHCR Operational Data Portal - Ethiopia.” Geneva: UNHCR. Available at:

https://data2.unhcr.org/en/country/eth.

2021c. “UNHCR Operational Data Portal - Kenya." Geneva: UNHCR. Available at:

https://data2.unhcr.org/en/country/ken.

Vemuru, V., R. Oka, R. Gengo, and L. Gettler. 2016. "Refugee Impacts on Turkana Hosts: A Social Impact Analysis for Kakuma Town and Refugee Camp, Turkana County, Kenya." Washington, DC and Geneva: World Bank/UNHCR.

Wake, Caitlin and Tania Cheung. 2016. "Livelihood Strategies of Rohingya Refugees in Malaysia." London: Humanitarian Policy Group, Overseas Development Institute. Available at: https://www.refworld.org/pdfid/57922bbb4.pdf.

Wake, Caitlin. 2016. “Turning a Blind Eye: The Policy Response to Rohingya Refugees in Malaysia." London: Humanitarian Policy Group, Overseas Development Institute. Available at:

https://cdn.odi.org/media/documents/11116.pdf.

World Bank. 2016. “Uganda's Progressive Approach to Refugee Management." Brief. Washington, DC: World Bank. Available at: https://www.worldbank.org/en/topic/fragilityconflictviolence/brief/ugandas-progressiveapproach-refugee-management.

. 2019. "Desk Review on Livelihoods and Self-Reliance for Refugees and Host Communities in Kenya." Washington, DC: World Bank. Available at:

https://documents1.worldbank.org/curated/en/685581553241680189/pdf/135485-WP-P169281-PUBLICLivelihoods.pdf.

Yusuf, Mohammad and Jamal Khalif. 2018. "Market Systems Analysis for Refugee Livelihoods in Jigjiga, Ethiopia." Geneva: International Labor Organization (ILO). 

